Chapman University

Chapman University Digital Commons

Food Science (MS) Theses

Dissertations and Theses

Spring 5-2020

\title{
Effect of Low Dose Irradiation on Expression of Genes Involved in Ethylene Biosynthesis of 'Granny Smith' Apples
}

\author{
Brian Nyakundi \\ Chapman University, nyakundi@chapman.edu
}

Follow this and additional works at: https://digitalcommons.chapman.edu/food_science_theses

Part of the Food Chemistry Commons, Food Processing Commons, and the Genetics and Genomics Commons

\section{Recommended Citation}

Nyakundi, Brian. (2020). Effect of low dose irradiation on expression of genes involved in ethylene biosynthesis of 'Granny Smith' apples. Master's thesis, Chapman University. https://doi.org/10.36837/ chapman.000146

This Thesis is brought to you for free and open access by the Dissertations and Theses at Chapman University Digital Commons. It has been accepted for inclusion in Food Science (MS) Theses by an authorized administrator of Chapman University Digital Commons. For more information, please contact laughtin@chapman.edu. 
Effect of Low Dose Irradiation on Expression of Genes Involved in Ethylene Biosynthesis of 'Granny Smith' Apples

A Thesis by

Brian Nyakundi

\author{
Chapman University \\ Orange, CA \\ Schmid College of Science and Technology \\ Submitted in partial fulfillment of the requirements for the degree of \\ Master of Science in Food Science
}

May 2020

Committee in charge:

Anuradha Prakash, Ph.D. (Chair)

Hagop Atamian, Ph.D. (Co-Chair)

Rosalee Hellberg, Ph.D. 
The thesis of Brian Nyakundi is approved.

\section{Anuradka Prak ash.}

Anuradha Prakash, Ph.D. (Chair)

Professor, Director, Food Science Program

Schmid College of Science and Technology

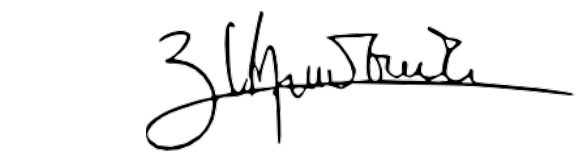

Hagop Atamian, Ph.D. (Co-Chair)

Assistant Professor, Biological Sciences Program

Schmid College of Science and Technology

Rosalee S. Hellberg

Rosalee Hellberg, Ph.D.

Associate Professor, Food Science Program

Schmid College of Science and Technology

March 2020 
Effect of Low Dose Irradiation on Expression of Genes Involved in Ethylene Biosynthesis of

\section{'Granny Smith' Apples}

Copyright $(\mathcal{C} 2020$

by Brian Nyakundi 


\section{ACKNOWLEDGEMENTS}

I would like to express my deep gratitude to Dr. Anuradha Prakash and Dr. Hagop Atamian, my research supervisors, for their patient guidance, enthusiastic encouragement and useful critiques of this research work. I would also like to thank my classmates who helped me with all my lab work. My grateful thanks are also extended to Dr. Criselda Toto Pacioles for her help in the statistical analysis. Finally, I wish to thank my family and friends for their support and encouragement throughout my study. 


\begin{abstract}
Effect of Low Dose Irradiation on Expression of Genes Involved in Ethylene Biosynthesis of 'Granny Smith' Apples

by Brian Nyakundi
\end{abstract}

Superficial scald is a physiological disorder characterized by skin browning that appears during or after storage of 'Granny Smith' apples. The mechanism for scald development is not fully understood, but it is hypothesized that scald formation is related to increased ethylene production. In apples, low dose irradiation induced ethylene reduction appears to be directly related to prevention of superficial scald. However, the molecular basis of such an irradiationinduced effect is not known. In this study, effort was made to better understand the molecular basis of the decrease in ethylene production in apple fruit after treatment with x-ray irradiation. 'Granny Smith' apples were exposed to x-ray irradiation treatment either at 310 Gy or 1000 Gy and ethylene production, ACC oxidase enzyme activity and expression of ethylene biosynthesis genes were measured after 0,90 , and 180 days of storage plus 7 days at room temperature. Ethylene production of irradiated apples was lower compared to control $(\mathrm{P}<0.05)$. No difference was observed in ACC oxidase activity at day 0, but irradiation at 310 Gy and 1000 Gy reduced ACC oxidase activity at days 90 and $180(\mathrm{P}<0.05)$. Irradiation treatment reduced the expression of ACS1, which coincided with reduced ethylene production and ACC oxidase enzyme activity. However, irradiation did not have a significant effect on ACS3, ACO1 and ACO2. Gene expression of $\alpha$-farnesene synthase was suppressed consistent with inhibition of superficial scald. 


\section{TABLE OF CONTENTS}

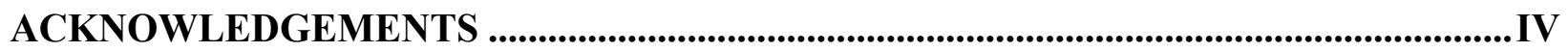

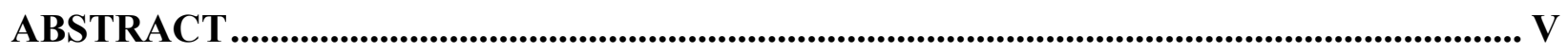

TABLE OF CONTENTS ........................................................................................................

LIST OF TABLES .................................................................................................................

LIST OF FIGURES .......................................................................................................................... IX

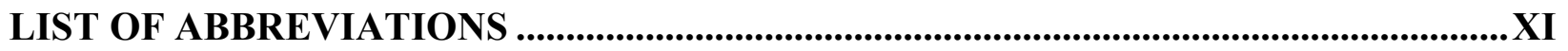

1. Introduction .................................................................................................................................. 1

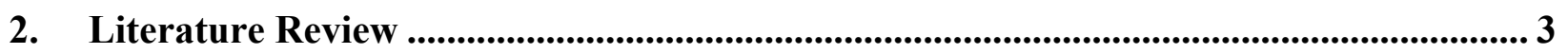

2.1. Ethylene production and role in fruit, climacteric fruit, apples ................................................ 3

2.1.1. Key enzymes involved in ethylene production ............................................................................

2.1.2. Gene expression of ACC synthase and oxidase …………...........................................................

2.2. Physiology of superficial scald and causes of scald on 'Granny Smith' apples ..................... 7

2.2.1. Role of ethylene in scald development in apple fruit........................................................................

2.2.2. Role of scald inhibitors on ethylene production and gene expression (for apples) ............................8

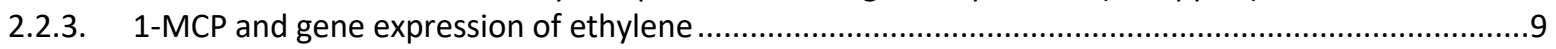

2.3. Phytosanitary treatment and irradiation ................................................................................. 10

2.4. Irradiation's effect on ethylene and superficial scald ............................................................. 11

2.5. Rationale and significance ................................................................................................................... 11

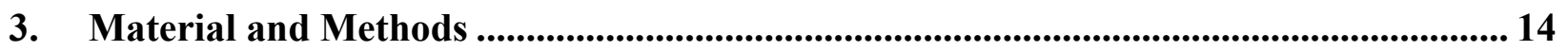

3.1. Plant materials and irradiation treatment ...................................................................... 14

3.2. ACC oxidase .................................................................................................................. 15

3.3. Total RNA extraction and purification ..................................................................................... 17

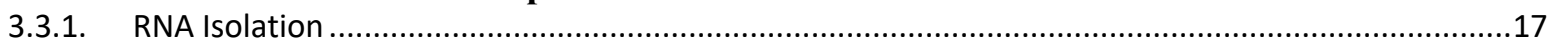

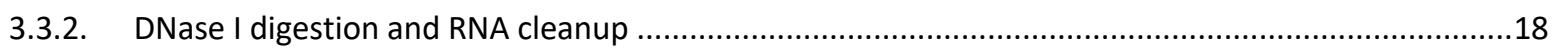

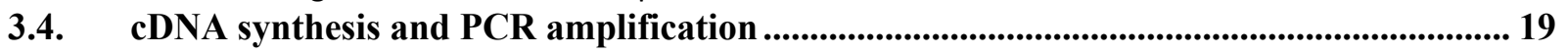

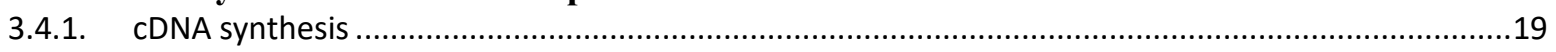

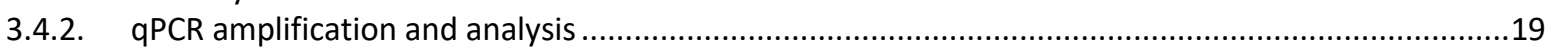

3.5. Statistical analysis..................................................................................................................... 20

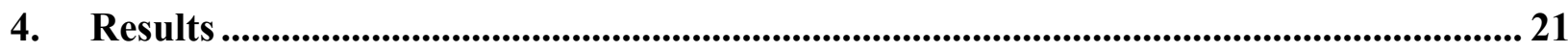

4.1. Effect of $\mathrm{x}$-ray irradiation on ACC oxidase enzyme activity............................................ 21

4.2. Effects of x-ray irradiation treatment on the expression of ACS1, ACO1 and ACO2 during postharvest ripening of apple fruit ...................................................................................... 22

4.3. Effects of $x$-ray irradiation treatment on the expression of $\alpha$-farnesene synthase gene AFS during postharvest ripening of apple fruit ..................................................................................... 24

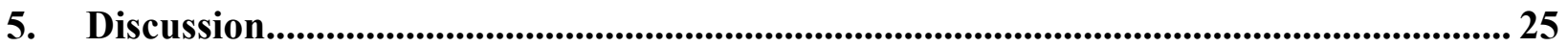

5.1. ACC oxidase enzyme activity and ethylene production............................................................. 25

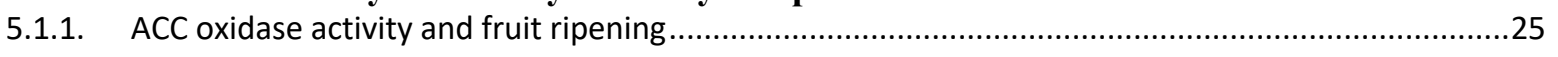


5.1.2. Effect of irradiation on ACC oxidase activity and ethylene production ............................................26

5.2. Expression of ethylene biosynthesis gene in Granny Smith apples ...................................... 28

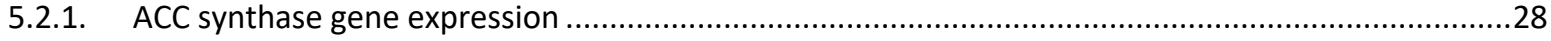

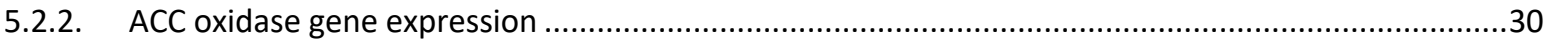

5.3. Influence of Ionizing Irradiation on gene expression ............................................................... 31

5.4. Reduction of superficial scald and $\alpha$-farnesene synthase gene expression .......................... 33

Conclusion ................................................................................................................................................ 35

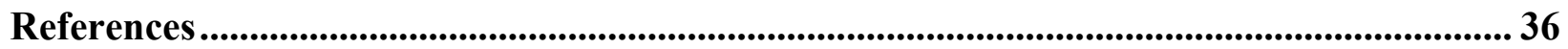




\section{LIST OF TABLES}

Table 1: ACC synthase and ACC oxidase gene studied in different apple cultivars.................. 6

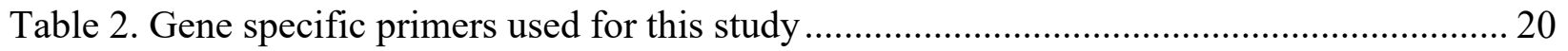




\section{LIST OF FIGURES}

Figure 1: Biosynthesis of ethylene pathway. Ethylene biosynthesis begins with SAM Synthetase converting methionine into SAM, then ACC synthase converts SAM into ACC, and finally ACC oxidase oxidizes ACC into ethylene (K. L. C. Wang, Li, \& Ecker, 2002). 5

Figure 2. Oxidation products of $\boldsymbol{\alpha}$-farnesene (PubChem CID: 5281516). Adapted from (Rowan et al., 2001).

Figure 3. Experimental design for plant material, irradiation treatment and tissue analysis....... 15

Figure 4. Sample preparation of apple tissue for RNA extraction. Liquid nitrogen was used to preserve sample throughout sample preparation.

Figure 5. Effect of irradiation (310 and $1000 \mathrm{~Gy}$ ) on the ACC oxidase (ACO) activity of 'Granny Smith' apples stored for 90 or 180 days at $0-1{ }^{\circ} \mathrm{C}$ followed by seven days of room temperature storage. Results are represented as mean values of three biological replicates and the error bars show the standard deviations. The letters A,B,C show differences due to treatment on the given day and the letters a,b,c show differences during storage for any given treatment $(\mathrm{P}<0.05)$.

Figure 6. Effect of irradiation on the expressions of Granny Smith ethylene biosynthesis genes, MdACS1 (A), MdACO1 (B), and MdACO2 (C) stored for 90 or 180 days at $0-1{ }^{\circ} \mathrm{C}$ followed by seven days of room temperature storage. The y axis represents the relative fold difference of mRNA levels and was calculated using a modified 2-DDCt formula (Wan and Wilkins, 1994) with MdPDI as reference. Results are represented as mean values of three biological replicates and the error bars show the standard deviations. Samples from Day 7 (assigned an arbitrary quantity of "1") were used as a calibrator to calculate relative gene expression. The letters $A, B, C$ show differences due to treatment on the given day and the letters a,b,c show differences during storage for any given treatment $(\mathrm{P}<0.05)$.

Figure 7. Effect of irradiation on the expressions of Granny Smith $\boldsymbol{\alpha}$-farnesene synthase gene, MdAFS, stored for 90 or 180 days at $0-1{ }^{\circ} \mathrm{C}$ followed by seven days of room temperature storage. The y axis represents the relative fold difference of mRNA levels and was calculated using a modified 2-DDCt formula (Wan and Wilkins, 1994) with MdPDI as reference. Results are represented as mean values of three biological replicates and the error bars show the standard deviations. Samples from Day 7 (assigned an arbitrary quantity of " 1 ") were used as a calibrator to calculate relative gene expression. The letters A,B,C show differences due to treatment on the given day and the letters $a, b, c$ show differences during storage for any given treatment $(\mathrm{P}<0.05)$.

Figure 8. Ethylene production, and ACC oxidase (ACO) activity in 'Granny Smith' apples irradiated (310 Gy, $1000 \mathrm{~Gy})$ and control, stored for 90 and 180 days at $0-1^{\circ} \mathrm{C}$ followed 
by 7 days at room temperature. Results are represented as mean values of three

biological replicates and standard errors are represented as error bars. ...................... 26 


\section{LIST OF ABBREVIATIONS}

DPA - Diphenylamine (PubChem CID: 11487)

1-MCP - 1-methyl-cyclopropene (PubChem CID: 151080)

SAM - S-adenosylmethionine synthetase (PubChem CID: 34756)

ACC - 1-aminocyclopropane-1-carboxylic acid (PubChem CID: 535)

ACS - ACC synthase

ACO - ACC oxidase

AFS - Alpha-farnesene synthase

MTA - 5-methylthioadenosine (PubChem CID: 439176)

U.S. - United States

USDA - United States Department of Agriculture

FDA - United States Food and Drug Administration

RNA - Ribonucleic acid

PCR - Polymerase chain reaction

qPCR - Real-time polymerase chain reaction

MOPS - 3-Morpholinopropane-1-sulfonic acid (PubChem CID: 70807)

CTAB - Cetrimonium bromide (PubChem CID: 5974)

DTT - Dithiothreitol (PubChem CID: 446094)

HCl - Hydrochloric acid (PubChem CID: 313)

EDTA - Ethylenediaminetetraacetic acid (PubChem CID: 6049)

NaCl - Sodium chloride (PubChem CID: 5234)

$\mathbf{L i C l}_{2}$ - Lithium chloride (PubChem CID: 433294)

$\mathbf{M g C l}_{2}$ - Magnesium chloride (PubChem CID: 5360315) 
Chemical compounds studied in this article:

Ethylene (PubChem CID: 6325)

Alpha-farnesene (PubChem CID: 5281516)

6-methyl-5-hepten-2-one (PubChem CID: 9862)

Glycerol (PubChem CID: 753)

Ascorbic acid sodium salt (PubChem CID: 23667548)

Sodium bicarbonate (PubChem CID: 516892)

Ferrous sulfate (PubChem CID: 24393)

Beta-mecaptoethanol (PubChem CID: 1567)

Chloroform (PubChem CID: 6212) 


\section{Introduction}

Apples are often stored at cold temperatures for up to 7 months after harvest and intermittently released into the market (Varela, Salvador, \& Fiszman, 2005). Following cold storage, apples warmed at ambient temperatures exhibit a physiological disorder known as superficial scald (Whitaker, 2004), characterized by skin browning, which can lead to product waste due to decrease in shelf-life and consumers' unwillingness to purchase defective apples (Dan et al., 2015). Apple fruit that is picked premature or marginally premature has an increased risk of scald development. For this reason, 'Granny Smith', 'Fuji', 'Law Rome' and 'Red Delicious' have the highest risk of scald development, especially Granny Smith as it is immaturely picked to maintain its green color (Blakey, 2014). The mechanism for scald development is not fully understood, but it is hypothesized that scald formation is related to increased ethylene production (C. B. Watkins, Bramlage, \& Cregoe, 1995). An increase in ethylene leads to increased production of $\alpha$-farnesene in the fruit's skin. Subsequent oxidation products of $\alpha$-farnesene include conjugated trienes which can cause cell death manifested as scald (Abdallah, Gil, Biasi, \& Mitcham, 1997). Currently, 'Granny Smith' apples are dipped in diphenylamine (DPA) which controls scald development by reducing $\alpha$-farnesene oxidation (Mir \& Beaudry, 1999). However, it is considered a carcinogen and can cause kidney failure and anemia (CDC, 2019). For these reasons, a number of Asian and European countries no longer accept the sale or import of fruit treated with DPA. Therefore, alternative methods of scald prevention need to be explored. 1-methyl-cyclopropene (1-MCP) is an ethylene inhibitor that irreversibly binds to ethylene receptors in plant cells, effectively inhibiting ethylene function and scald development (Bris, 2003). The inhibitory effect of 1-MCP inhibitory is dependent on the fruit, cultivar, storage conditions and treatment temperature and duration. The efficacy of 1-MCP 
on ethylene production is seen to diminish during extended storage. Additionally, consumer movement towards "clean and green" chemical-free produce makes finding alternative methods to DPA and 1-MCP necessary (Aschemann-Witzel, Varela, \& Peschel, 2019).

Irradiation is approved as a phytosanitary treatment for fruit and is used for various fruit imported into the United States such as guavas from Mexico, mangoes from Australia, India and Mexico, and dragon fruit from Vietnam (Hallman \& Loaharanu, 2016). Ethylene production in apples has been observed to decrease with increasing irradiation starting at $0.44 \mathrm{kGy}$ (Fan \& Mattheis, 2001). Reduced scald formation has been observed in irradiated apples (Massey Jr., Parsons, \& Smock, 1964), but the connection between irradiation-induced ethylene suppression and suppression of scald in apples has not been explored (Iacovides \& Meiring, 2018).

Irradiation of 'Granny Smith' apples decreases the activity of ACC oxidase, a key enzyme responsible for production of ethylene (Paul \& Pandey, 2014). However, it is not known if irradiation inactivates the key enzymes involved in ethylene biosynthesis, or if it affects gene expression of the enzyme and reduces their formation. Understanding the mechanism by which ethylene production is reduced could be helpful in controlling the occurrence of superficial scalding in apples and subsequently other fruit such as pears in which scald disorder is common.

Our hypothesis is that $\mathrm{x}$-ray irradiation lowers the expression of genes in the ethylene biosynthesis pathway, causing a decrease in ethylene production and subsequent inhibition of superficial scalding (Du, Song, Palmer, Fillmore, \& Zhang, 2017). Specifically, lower gene expression is responsible for decreased ACC oxidase activity and ethylene production and inhibition of scald development after x-ray irradiation. This work could provide insight into how irradiation affects the genes involved in ethylene biosynthesis for apples and other biological processes in fruit. 


\section{Literature Review}

2.1. Ethylene production and role in fruit, climacteric fruit, apples

Ethylene is a naturally occurring two carbon gas found in plants that enhances fruit ripening and senescence. Considered a plant hormone, ethylene regulates the growth, development and storage life of fruits and vegetables (Saltveit, 1999). Plants produce ethylene during stages of growth, ripening, leaf abscission and flower senescence. All plant tissues can produce ethylene, but production levels differ depending on the plant. Ethylene production also increases when plants are subjected to stress or application of growth regulators (Kende, 1993). During ripening, ethylene is responsible for changes in texture, color, firmness, taste and flavor, aroma, and other developmental factors that occur during ripening (Saltveit, 1999). In non-climacteric fruits such as strawberries and oranges, ethylene production is low since these fruits do not ripen further once harvested. On the other hand, apples, which are climacteric continue to ripen after harvest and depend on ethylene production to induce the ripening process.

As climacteric fruits such as apples start to ripen, respiration, which is a measure of metabolic activity slowly declines to a near resting stage, then increases rapidly signaling the start of fruit ripening. During ripening, ethylene production significantly increases and changes in fruit characteristics such as softening and color change (Saltveit, 1999). The role of ethylene in apple ripening has been studied is well documented (Kende, 1993). When ethylene is suppressed or inhibited using 1-methylcyclopropene (1-MCP) (Jung \& Watkins, 2014) or other methods such as ethylene scrubbing or aminoethoxyvinylglycine (AVG) (Yuan \& Carbaugh, 2007), a significant reduction in ripening is observed. In apples, a key indicator of ripening is the softening of the flesh tissue. Ethylene-induced characteristic changes during ripening such as color change and change in volatiles have also been observed (Ireland et al., 2014). 


\subsubsection{Key enzymes involved in ethylene production}

To better understand ethylene's role in plant growth and development, it is important to look at how ethylene is synthesized. $S$-adenosylmethionine synthetase (SAM synthetase) converts methionine into SAM, followed with the conversion of SAM to 1-aminocyclopropane-1carboxylic acid (ACC) by ACC synthase (ACS), and finally ACC oxidase (ACO) oxidizes ACC to form ethylene (S. F. Yang \& Hoffman, 1984). These steps of the ethylene biosynthesis pathway are presented in Figure 1. ACC synthase also produces 5-methylthioadenosine (MAT) in the same reaction as ACC, MAT is then recycled back to methionine allowing for continuous ethylene production (Bleecker \& Kende, 2000). 


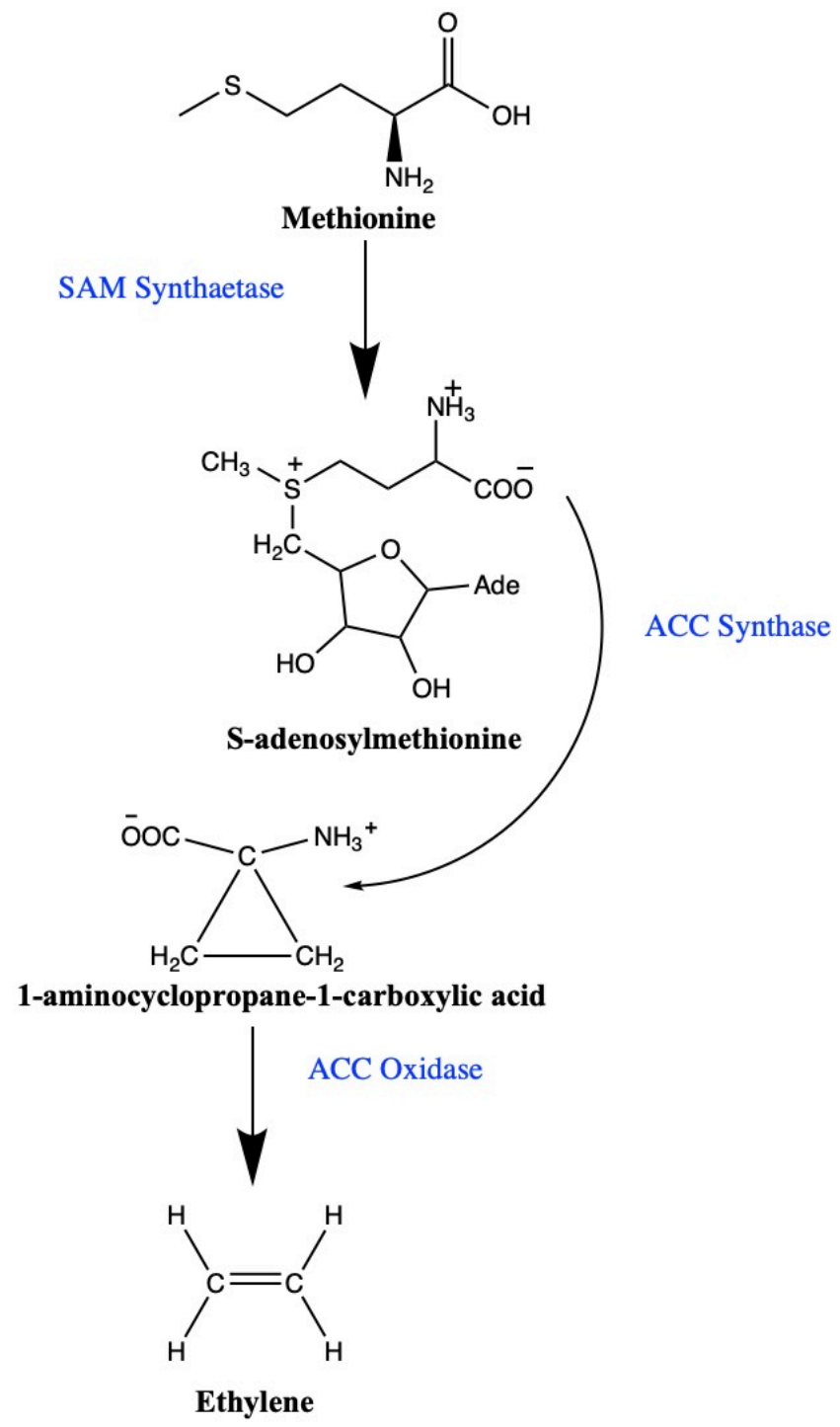

Figure 1: Biosynthesis of ethylene pathway. Ethylene biosynthesis begins with SAM Synthetase converting methionine into SAM, then ACC synthase converts SAM into ACC, and finally ACC oxidase oxidizes ACC into ethylene (K. L. C. Wang, Li, \& Ecker, 2002).

\subsubsection{Gene expression of ACC synthase and oxidase}

Ethylene biosynthesis is regulated by two key enzymes, ACC synthase (ACS) and ACC oxidase (ACO). ACS and ACC OXIDASE gene families have been identified in multiple fruits that produce ethylene such as: tomato, melon, apple, pear, peach, and kiwifruit (Bulens et al., 2014; Rudus, Sasiak, \& Kepczynski, 2013; Shi \& Zhang, 2012). In apples, nineteen ACS genes 
(T. Li, Tan, Yang, \& Wang, 2013; Varanasi, Shin, Mattheis, Rudell, \& Zhu, 2011) and four ACC oxidase genes have been identified. Five of the nine ACS genes and three of the six ACC oxidase genes are related to fruit ripening(Asif, Pathak, Solomos, \& Trivedi, 2009). Genes involved in ethylene biosynthesis are displayed in Table 1.

Table 1: ACC synthase and ACC oxidase gene studied in different apple cultivars.

\begin{tabular}{|c|c|c|c|c|}
\hline Fruit name & Enzyme & Gene name & Effects & Reference \\
\hline $\begin{array}{l}\text { Golden } \\
\text { Delicious }\end{array}$ & $\begin{array}{l}\text { ACC } \\
\text { synthase }\end{array}$ & $\begin{array}{l}\text { ACS1, } \\
\text { ACS3a, } \\
\text { ACS6 } \\
\text { ACS7, } \\
\text { ACS8, and } \\
\text { ACS9. }\end{array}$ & $\begin{array}{l}\text { Three of the six genes studied were } \\
\text { inhibited by 1-MCP an ethylene } \\
\text { inhibitor. }\end{array}$ & (T. Li et al., 2013) \\
\hline $\begin{array}{l}\text { Golden } \\
\text { Delicious }\end{array}$ & $\begin{array}{l}\text { ACC } \\
\text { synthase } \\
\text { ACC } \\
\text { oxidase }\end{array}$ & $\begin{array}{l}\text { ACS1 and } \\
\text { ACS } 2 \\
\text { ACO1, } \\
\text { ACO2, and } \\
\text { ACO3 }\end{array}$ & $\begin{array}{l}\text { ACS1 and ACO1 genes were } \\
\text { significantly up-regulated in fruit } \\
\text { during ripening. 1-MCP treatment } \\
\text { significantly inhibited expression } \\
\text { of ACS1, ACO1 and ACO2 ethylene } \\
\text { biosynthesis genes }\end{array}$ & $\begin{array}{l}\text { (X. Yang, Song, } \\
\text { Campbell-Palmer, } \\
\text { Fillmore, \& Zhang, } \\
\text { 2013) }\end{array}$ \\
\hline $\begin{array}{l}\text { Prima, Fuji, } \\
\text { Mondial } \\
\text { Gala, } \\
\text { Braeburn, } \\
\text { Fiesta }\end{array}$ & $\begin{array}{l}\text { ACC } \\
\text { synthase } \\
\text { ACC } \\
\text { oxidase }\end{array}$ & $\begin{array}{l}\text { ACS1 } \\
\text { ACO1 }\end{array}$ & $\begin{array}{l}\text { ACS1 and ACO1 independently } \\
\text { affect the internal ethylene } \\
\text { concentration (IEC) as well as shelf } \\
\text { life of apple, ACS1 having the } \\
\text { strongest effect. }\end{array}$ & (Costa et al., 2005) \\
\hline $\begin{array}{l}\text { Granny } \\
\text { Smith }\end{array}$ & $\begin{array}{l}\text { ACC } \\
\text { synthase } \\
\text { ACC } \\
\text { oxidase }\end{array}$ & $\begin{array}{l}\text { ACS1 and } \\
\text { ACS3 } \\
\text { ACO1 }\end{array}$ & $\begin{array}{l}\text { expression of ACS1 was shown to } \\
\text { be markedly affected by the } \\
\text { application of 1-MCP and low O2 } \\
\text { treatments. The expression of ACS1 } \\
\text { has also been shown to be reduced } \\
\text { by the application of 1-MCP }\end{array}$ & (Asif et al., 2009) \\
\hline $\begin{array}{l}\text { Honeycrisp } \\
\text { McIntosh }\end{array}$ & $\begin{array}{l}\text { ACC } \\
\text { synthase } \\
\text { ACC } \\
\text { oxidase }\end{array}$ & $\begin{array}{l}\mathrm{ACS} 1 \text { and } \\
\mathrm{ACS} 3 \\
\mathrm{ACO} 1 \text { and } \\
\mathrm{ACO} 2\end{array}$ & $\begin{array}{l}\text { The expression of ACO1, ACO2 and } \\
\text { ACS1 tended to be higher at lower } \\
\text { IECs in 'Honeycrisp' than in } \\
\text { 'McIntosh'. }\end{array}$ & $\begin{array}{l}\text { (Harb, Gapper, } \\
\text { Giovannoni, \& } \\
\text { Watkins, 2012) }\end{array}$ \\
\hline
\end{tabular}




$\begin{array}{lllll}\text { Royal Gala } & \begin{array}{l}\mathrm{ACC} \\ \text { oxidase }\end{array} & \begin{array}{l}\mathrm{ACO} 1, \\ \mathrm{ACO} 2, \text { and } \\ \mathrm{ACO} 3\end{array}\end{array} \quad \begin{aligned} & \mathrm{ACO} 1, \mathrm{ACO} 2 \text { and } \mathrm{ACO} 3 \text { are } \\ & \text { differentially expressed in apple fruit }\end{aligned} \quad \begin{aligned} & \text { (Binnie \& } \\ & \text { McManus, 2009) }\end{aligned}$

\subsection{Physiology of superficial scald and causes of scald on 'Granny Smith' apples}

Apples can be stored for up to 12 months in cold storage. However, postharvest disorders such as superficial scald can limit long term apple storage, costing the apple industry millions of dollars in losses each year. Superficial scald is a post-harvest physiological disorder that affects certain cultivars of apples and pears. 'Granny Smith', 'Fuji' and 'Red Delicious' apples are highly susceptible to superficial scald due to early harvesting and premature storage (Blakey, 2014; C. B. Watkins et al., 1995). Superficial scald is characterized by the development of brown and black spots on the peel after fruit has been removed from cold storage (Whitaker, 2004). Scald disorder caused by exposure to warm temperatures after removal from cold storage, which allows symptoms developed during cold storage to manifest causing scald. Superficial scald is a two-stage event, meaning the damage occurs first and the symptoms from the damage are developed later. (C. B. Watkins et al., 1995) observed changes in chemical composition of 'Granny Smith' apples immediately during warming but scald development was not observed until many weeks later.

\subsubsection{Role of ethylene in scald development in apple fruit}

The brown discoloration observed as a result of superficial scald results from cell death in the epidermis and hypodermal cortical tissues of apples (Watkins et al, 1995). The disorder is induced by the oxidation of $\alpha$-farnesene, a compound present in the wax of apple fruit. As seen in Figure 2, oxidation of $\alpha$-farnesene results in highly reactive conjugated trienes hydroperoxide, conjugated trienol, or 6-methyl-5-hepten-2-one, which accumulate in the skin 
tissue and are suspected to be the agents responsible for scalding. (Rowan, Hunt, Fielder, Norris, \& Sherburn, 2001).

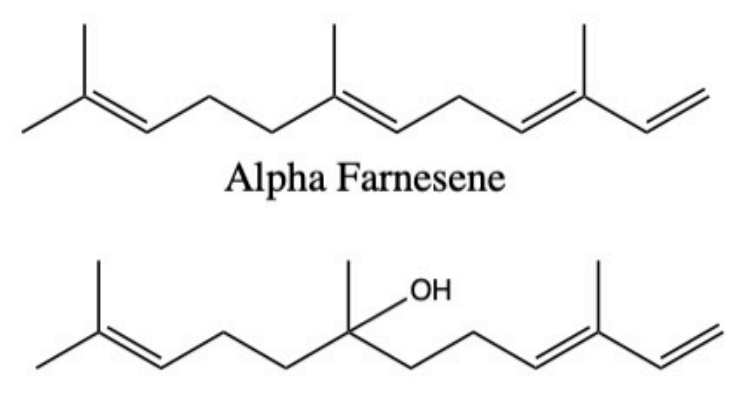

Conjugated Trienol
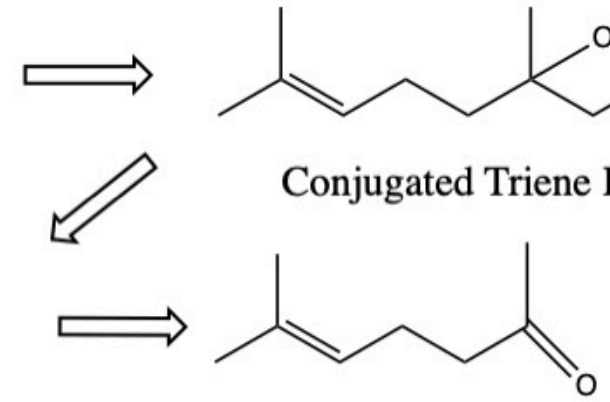

6-Methyl-5-hepten-2-one

Figure 2. Oxidation products of $\alpha$-farnesene (PubChem CID: 5281516). Adapted from (Rowan et al., 2001).

Trienes react with lipids and proteins, interfering with cell integrity and resulting in oxidative enzymes that cause brown discoloration and cell death (Abdallah et al., 1997). During cold storage, apples produce low levels of ethylene. After removal from cold storage they begin to ripen at ambient temperature and ethylene production significantly increases (Gussman, Goffreda, \& Gianfagna, 1993). Ethylene and $\alpha$-farnesene production in 'Granny Smith' apples gradually increase as scald severity progressed (Mditshwa et al., 2016). This relationship has been observed in multiple studies suggesting that production of $\alpha$-farnesene is dependent on ethylene (Savran \& Koyuncu, 2016; C. B. Watkins et al., 1995; Whitaker, 2004).

\subsubsection{Role of scald inhibitors on ethylene production and gene expression (for apples)}

Ethylene inhibitors can also be useful in the produce industry. Exogenous application of ethylene is used commercially to assist in the ripening of climacteric fruits such as bananas. Avoidance of ethylene exposure or minimization of its production and action is critical in controlling ripening and senescence of fruit, specifically climacteric fruit (Chris B. Watkins, 
2006). In apples, increased ethylene production can lead to increased $\alpha$-farnesene synthesis thus increasing apples susceptibility to scald development. Therefore, it is advantageous for the apple industry to control ethylene production during and after storage. For the apple industry, the most commonly used methods of ethylene reduction and inhibition include diphenylamine (DPA) treatment, 1- methylcyclopropane (1-MCP) application, and low oxygen and low temperature storage (Asif et al., 2009; Du et al., 2017; Chris B. Watkins, 2006). Diphenylamine (DPA) is mainly used as a pre- and postharvest treatment to control scald disorder. Moggia, Moya-Leon, Pereira, Yuri, \& Lobos (2010) observed that apples treated with DPA and stored at $0{ }^{\circ} \mathrm{C}$ for 180 days had lower (13 $\left.\mu \mathrm{L} \mathrm{kg}^{-1} \mathrm{~h}^{-1}\right)$ ethylene production, compared to untreated apples which showed higher (23 $\left.\mu \mathrm{L} \mathrm{kg}^{-1} \mathrm{~h}^{-1}\right)$ ethylene production. On the other hand, 1- methylcyclopropane (1-MCP) does not inhibit ethylene production but its action in fruit. 1-MCP is structurally similar to ethylene so it is able to tightly bind to ethylene receptors, thereby blocking the effects of ethylene. Treatment of 'Granny Smith' apples with 1-MCP resulted in no ethylene production during ripening and no visible scald symptoms after eight days of ripening (Karagiannis et al., 2018). 1-MCP treatment prior to storage is believed to block existing ethylene receptors, however fruit are able to form new ethylene receptors during storage therefore reducing the sensitivity and inhibitory effects of 1-MCP over time (Blankenship \& Dole, 2003; Zhou, Cheng, \& Guan, 2017). Low oxygen and low temperature storage is another method used to effectively control ethylene production in apples (Saltveit, 1999).

\subsubsection{1-MCP and gene expression of ethylene}

Ethylene inhibitors can play a role in the regulation and expression of genes involved in the ethylene biosynthesis pathway. Ethylene inhibitor, 1-MCP can down regulate expression of genes involved in ethylene biosynthesis, specifically genes expressed during fruit ripening (X. 
Yang et al., 2013). ACS1 and ACO1 genes are upregulated during fruit ripening. However, apples treated with 1-MCP exhibited a significant inhibition of ACS1 and ACO1 (X. Yang et al., 2013). Low temperature and low oxygen are also used to control ethylene production in apples. 'Granny Smith' apples subjected to these conditions as well as 1-MCP showed no transcript for ACS1 (Asif et al., 2009). These results suggest that inhibition or reduction of ethylene production can result is the down regulation of specific genes involved in ethylene biosynthesis.

\subsection{Phytosanitary treatment and irradiation}

Phytosanitary treatments include chemical (dips, sprays or fumigation), and physical (cold, heat and irradiation) (Hennessey et al., 2014). These treatments are used to kill, inactivate, or remove pests for plants or plant material control and prevent the introduction and spread of regulated pests of plants and plant products. Fumigation is a common phytosanitary treatment for apples. Methyl bromide, phosphine, and sulfuryl fluoride are the three fumigants approved for treatment use in the United States (U.S.), with methyl bromide being the most commonly used because of its ability to treat a wide variety of plant pests (Hennessey et al., 2014). However, the use of methyl bromide has being phased out because of its contribution to the depletion of the ozone layer (Hennessey et al., 2014). Non-chemical conventional phytosanitary treatment includes cold treatment, heat treatment, and irradiation.

Irradiation can be used as a postharvest treatment to prolong shelf-life and enhance safety of fruits and vegetables. The U.S. Department of Agriculture (USDA) and U.S. Food and Drug Administration (FDA) have approved use of irradiation as an insect disinfectant and shelf-life extender for fruits and vegetables at a maximum dose of $1.0 \mathrm{kGy}$ (FDA, 2018) The use of irradiation as a phytosanitary treatment has been increasing since 2000 , when the first irradiation treatment facility was built in Hawaii. (Hennessey et al., 2014). Since then, the U.S. has allowed 
for the import of irradiated products such as mangos from India and guavas from Mexico (Hallman \& Loaharanu, 2016). As of 2015, irradiation as a phytosanitary treatment was used on approximately 25 thousand tons of fruits and vegetables and the number is growing at a rate of 2,500 tons per year since 2007 (Hallman \& Loaharanu, 2016).

\subsection{Irradiation's effect on ethylene and superficial scald}

Irradiation can also be used as a treatment to reduce the occurrence of superficial scald in apple fruit. 'Rome Beauty', 'McIntosh', and 'Cortland' apples treated with 0.5 and $1.0 \mathrm{kGy}$ of gamma irradiation had progressively less storage scald with increasing dosage (Massey Jr. et al., 1964). Reduction of scald after irradiation treatment could be attributed to a reduction in ethylene production (Mditshwa et al., 2016). 'Gala' apples treated with different doses of irradiation $(0.5,1.0$ and $1.5 \mathrm{kGy})$ produced less ethylene over a 21-day period when compared to controls (Fan, Argenta, \& Mattheis, 2001). Ethylene reduction was also observed when 'Gala' apples were treated with $0.44,0.88$, or $1.32 \mathrm{kGy}$ of irradiation (Fan \& Mattheis, 2001). Furthermore, irradiation of 'Gala' apples at $0.44,0.88$ and $1.32 \mathrm{kGy}$ reduced the accumulation of 6-methyl-5-hepten-2-one, a compound suspected of causing superficial scald (Fan \& Mattheis, 2001). The effect of irradiation on gene expression in apples has yet to be investigated, therefore this study would be the first to report on the effect of x-ray irradiation on the expression of ethylene biosynthesis genes.

\subsection{Rationale and significance}

Superficial scalding disorder in 'Granny Smith' apples is a concern for the apple industry, as it can lead to product loss. Currently, diphenylamine (DPA) is commercially used to control scalding and internal browning in apples in the United States. However, the European commission and 28 other countries have banned the use of DPA for apple treatment, as it is seen 
as a pollutant and possible carcinogen (Calvo, 2010). 'Granny Smith' apples are also treated with methyl bromide phytosanitary fumigation for pest control (Meadows, 2013). However, methyl bromide is an ozone depleting chemical and is currently in the process of being phased out (Meadows, 2013). 1-methyl-cyclopropene (1-MCP) is a chemical commercially used to slow down ripening and extend shelf-life in fruit. It is an ethylene inhibitor that irreversibly binds to ethylene receptors in plant cells, therefore effectively inhibiting ethylene production and inhibiting scald development (Bris, 2003). However, 1-MCP efficacy is depended on multiple factors (cultivar, storage conditions and treatment temperature and duration) and its effect on ethylene production is seen to disappear during extended cold storage. Consumers are not comfortable with the use of herbicides, insecticides, chemical sprays, and preservatives on their foods (Aschemann-Witzel et al., 2019). Therefore, a long term, safe and chemical-free method to control the development of scald would be of great benefit.

Phytosanitary irradiation is an approved, nonchemical alternative to DPA and methyl bromide for controlling pest in fruits and vegetables at a maximum dose of $1.0 \mathrm{kGy}$ (FDA, 2018). Apples treated with irradiation show a decrease in ethylene production and development of superficial scald (Fan \& Mattheis, 2001; Massey Jr. et al., 1964). Irradiation induced reduction in ethylene appears to be directly related to prevention of superficial scald however, the connection between irradiation-induced ethylene suppression and the reduction of scald in apples has not been explored (Iacovides \& Meiring, 2018). Irradiation also affects ACC oxidase activity, a key enzyme in the biosynthesis of ethylene (Paul \& Pandey, 2014), however, the mechanism by which irradiation affects enzyme activity is unclear.

The goal of this research project is to determine how ethylene production in 'Granny Smith' apples is reduced at the genomic level after irradiation treatment. This study aims to: 
1. Determine if $x$-ray irradiation lowers the expression of genes in the ethylene biosynthesis pathway (Du et al., 2017).

2. Better understand the molecular effects of irradiation on ethylene biosynthesis genes and enzymes and correlate irradiation-induced reduced ethylene with inhibition of superficial scald formation (Karagiannis et al., 2018). 


\section{Material and Methods}

\subsection{Plant materials and irradiation treatment}

Ten boxes $(51 \mathrm{~cm} \times 33 \mathrm{~cm} \times 30.5 \mathrm{~cm})$ of 'Granny Smith' apples were harvested from an orchard in Stockton, CA. The fruit ( 6 boxes) was transported $130 \mathrm{~km}$, to the irradiation facility (Steri-tek, Fremont California) in a refrigerated van for x-ray irradiation treatment. For each dose level (310 Gy and 1000Gy), two boxes of apples were irradiated, and two control boxes were left outside the irradiation chamber during treatment to simulate similar treatment conditions as the irradiated boxes. Alanine (Kodak, Rochester, NY) and gafchromic (GEX Corporation, Centennial, CO) film dosimeters were placed in the boxes for dose mapping. After treatment, the six boxes were transported $378 \mathrm{~km}$ to Chapman University (Orange, CA) and placed in cold storage $\left(0-1^{\circ} \mathrm{C}\right)$ for analysis. Irradiated and control fruit samples were taken out of cold storage after 0,90 and 180 days; and their ethylene production rate, $\alpha$-farnesene concentration, and scald severity were determined. The fruit were separated into peel and flesh, cut into small pieces, immediately flash frozen with liquid nitrogen, and stored at $-80^{\circ} \mathrm{C}$ for enzyme activity and genomic analysis. The experimental design for plant material, irradiation treatment, fresh tissue, and frozen tissue analysis are outlined in Figure 3 and, respectively. 


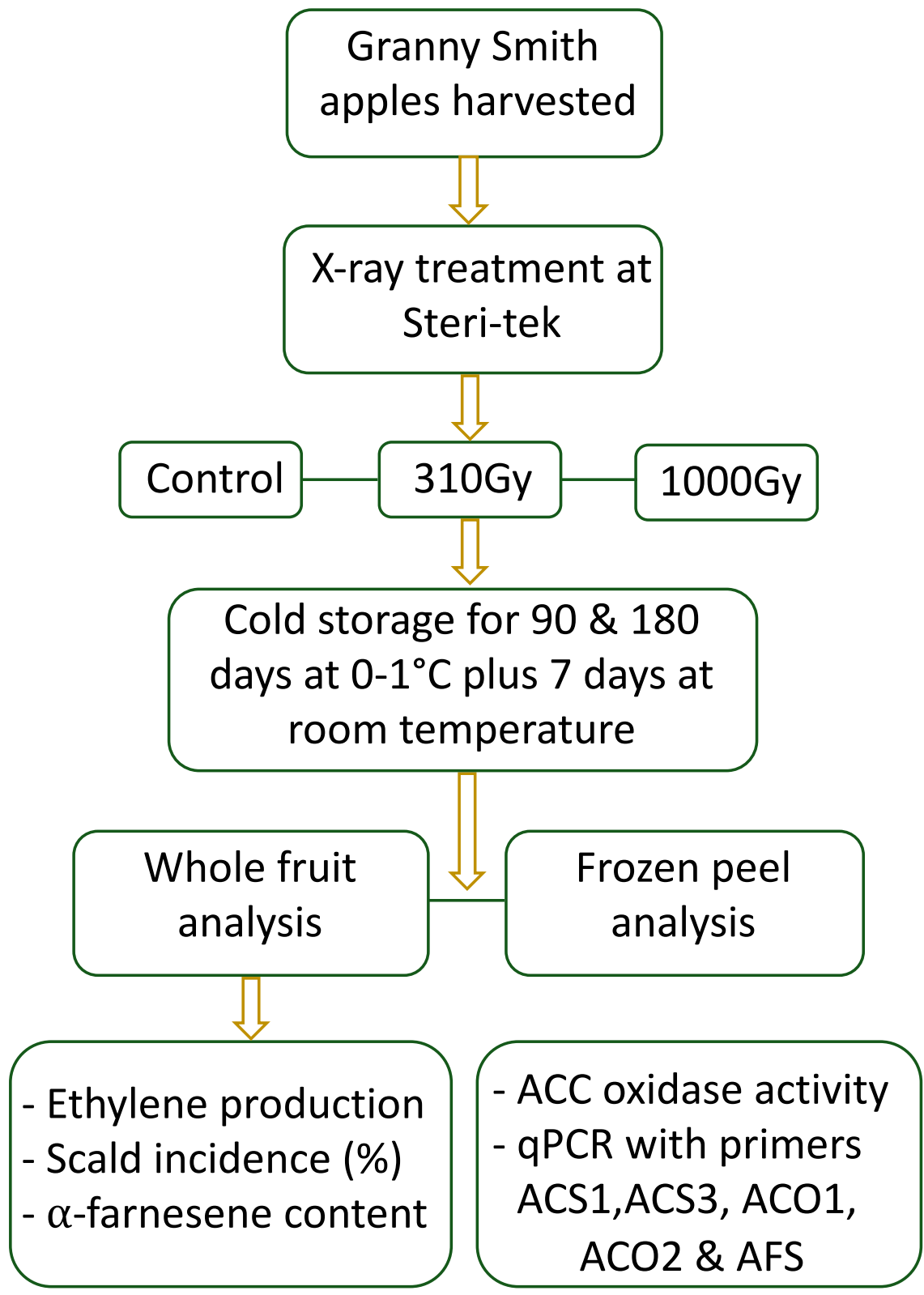

Figure 3. Experimental design for plant material, irradiation treatment and tissue analysis

\subsection{ACC oxidase}

ACC oxidase enzyme activity was determined as described by (Bulens et al., 2011) with slight modifications. 3-Morpholinopropane-1-sulfonic acid (MOPS) extraction buffer (400 mM, $\mathrm{pH}$ 7.2) was prepared by dissolving $8.370 \mathrm{~g}$ of MOPS in $50 \mathrm{~mL}$ of distilled water (DI). $10 \mathrm{~mL}$ of glycerol $(10 \% \mathrm{v} / \mathrm{v})$ and $0.594 \mathrm{~g}$ of ascorbic acid sodium salt $(30 \mathrm{mM})$ were then added and the 
$\mathrm{pH}$ was adjusted to 7.2 using $1 \mathrm{M} \mathrm{NaOH}$ solution. The solution was transferred into a $100 \mathrm{~mL}$ volumetric flask and DI water was added to reach a total volume of $100 \mathrm{~mL}$. MOPS reaction buffer (50 mM, pH 7.2) was prepared by dissolving $1.046 \mathrm{~g}$ of MOPS, $0.099 \mathrm{~g}$ of ascorbic acid sodium salt $(5 \mathrm{mM}), 0.168 \mathrm{~g}$ of sodium bicarbonate $(20 \mathrm{mM})$ and $0.010 \mathrm{~g} \mathrm{ACC}(1 \mathrm{mM})$ in a 150 $\mathrm{ml}$ beaker with DI water, then adding $10 \mathrm{~mL}$ of glycerol $(10 \% \mathrm{v} / \mathrm{v}), 0.015 \mathrm{~g}$ DTT $(1 \mathrm{mM})$, and $0.3 \mathrm{mg}$ of iron sulphate $(0.02 \mathrm{mM})$. A stock solution of ferrous sulphate was made by weighing $0.1112 \mathrm{~g}$ of ferrous sulphate and was made up to $200 \mathrm{~mL}$ using DI water. $1 \mathrm{~mL}$ of the stock solution was added to the buffer and the $\mathrm{pH}$ was adjusted to 7.2 using $\mathrm{NaOH}$ solution. In a volumetric flask, the buffer was made up to $100 \mathrm{~mL}$ using DI water. $0.1 \mathrm{~g}$ of frozen peel tissue powder and $0.3 \mathrm{~g}$ of polyvinylpolypyrrolidone (PVPP) were weighed out in a $50 \mathrm{~mL}$ falcon tube while keeping cold on ice, to prevent enzyme activity loss. $6 \mathrm{~mL}$ of extraction buffer was added to the falcon tube and the slurry was placed in a $1.5 \mu l$ microcentrifuge tube and centrifuged at $21,000 \mathrm{~g}$ for $30 \mathrm{~min}$ at $4^{\circ} \mathrm{C}$. The supernatant was collected and placed on ice. $800 \mu \mathrm{l}$ of supernatant was transferred into a $15 \mathrm{~mL}$ glass vial and $3.2 \mathrm{~mL}$ of MOPS reaction buffer was added. The vial was immediately vortexed for 5 seconds, then incubated in a shaking water bath $\left(30^{\circ} \mathrm{C}\right)$ at $55 \mathrm{rpm}$ for 40 minutes. After incubation, the vial was vortexed to release all the gas into the headspace and $1 \mathrm{~mL}$ of gas from the headspace injected into a gas chromatography to measure ethylene production. Amount of ethylene was determined using Equation 1 and

\section{Equation 2.}




\section{Equation 1.}

$$
n_{\text {sample }}(m o l)=\left(E t h_{\text {sample }}-\frac{E t h_{\text {blank }}}{2}\right) \cdot 10^{-6} \cdot \frac{P_{i} V_{\text {free }}}{R . T}
$$

$E t h_{\text {sample }}$ and $E t h_{\text {blank }}$ are sample and blank measurements respectively

$P_{i}(\mathrm{~Pa})$ is the pressure of the system before measurement

$V_{\text {free }}\left(\mathrm{m}^{3}\right)$ is the free headspace volume

$R$ the universal gas constant $(8.314$ J.mol-1.K-1) and $T$ the temperature $(\mathrm{K})$.

Equation 2.

$$
A C O_{\text {activity }}=\frac{n_{\text {sample }} \cdot V_{\text {extract }}}{V_{\text {reading }} \cdot w \cdot t}
$$

$V_{\text {extract }}(\mathrm{mL})=$ volume of liquid in sample after extraction

$V_{\text {reading }}(\mathrm{mL})=$ amount of extract used

$w$ (g fresh weight) the weight of the sample and $t$ (hours) the incubation time.

\subsection{Total RNA extraction and purification}

\subsubsection{RNA Isolation}

Frozen peel tissue was ground into a fine powder in liquid nitrogen using a mortar and pestle (Thermo Fisher Scientific, CA) as shown in Figure 4. The peel powder was then transferred to a $2.0 \mathrm{~mL}$ microcentrifuge tube and $700 \mu \mathrm{L}$ of extraction buffer (CTAB, PUP, $1 \mathrm{M}$ tris $\mathrm{HCl}(\mathrm{pH} 8)$, 0.5M EDTA ( $\mathrm{pH} 8$ ), 5M NaCl, nuclease free water, and beta-mecaptoethanol) was added. The tubes were then vortexed briefly and heated at $65^{\circ} \mathrm{C}$ for $10 \mathrm{~min} .700 \mu \mathrm{L}$ of chloroform (SigmaAldrich, St. Louis, MO) was added to the mixture and the tubes were centrifuged (14,000 rpm) at $4^{\circ} \mathrm{C}$ for $10 \mathrm{~min}$. The chloroform step was repeated with $500 \mu L$ of the supernatant and $500 \mu L$ of chloroform. $200 \mu L$ of the resulting supernatant was transferred to a new microcentrifuge tube and $50 \mu \mathrm{L}$ of $8 \mathrm{M} \mathrm{LiCl}_{2}$ was add to each tube. The tubes were mixed with inversion and stored 
overnight at $-20^{\circ} \mathrm{C}$. Tubes were then centrifuged at $14,000 \mathrm{rpm}$ for 30 minutes at $4{ }^{\circ} \mathrm{C}$. The supernatant was discarded, and the pellet was washed with $700 \mu l 70 \%$ ethanol, centrifuged at $14,000 \times \mathrm{g}$ for 10 minutes at $4{ }^{\circ} \mathrm{C}$, then the supernatant was discarded. The tubes were allowed to dry at room temperature for 15 minutes and the pellet was dissolved in $20 \mu l$ of nuclease free water. Total RNA was quantified using a Nanodrop 2000 spectrophotometer (NanoDrop Technologies, Wilmington, DE).
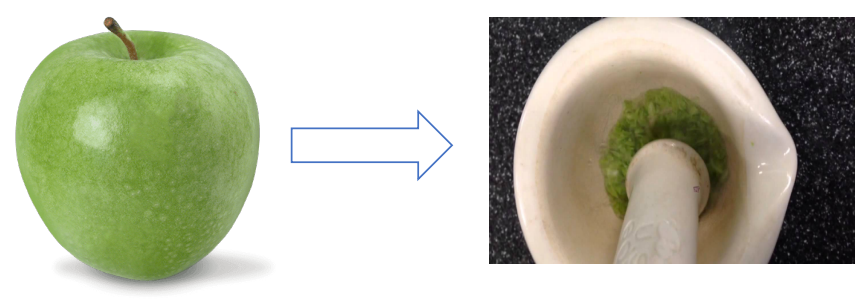

Apple tissue was separated into peel and flesh
Tissue was placed pre cooled mortar and ground it powder with liquid nitrogen

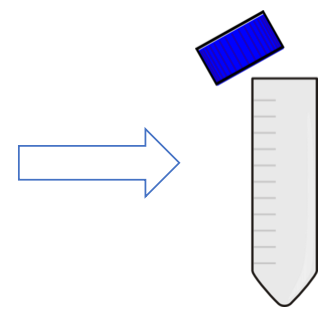

Tissue was transferred into a pre cooled $50 \mathrm{ml}$ falcon tube

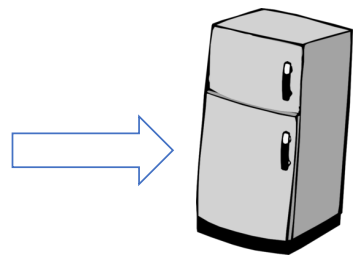

The falcon tube was place in $-80^{\circ} \mathrm{C}$ freezer

Figure 4. Sample preparation of apple tissue for RNA extraction. Liquid nitrogen was used to preserve sample throughout sample preparation.

\subsubsection{DNase I digestion and RNA cleanup}

Total RNA samples were transferred to a $2 \mathrm{~mL}$ microcentrifuge tube , and $500 \mu l$ of lysis buffer from Spectrum Plant Total RNA Kit (Sigma-Aldrich, St. Louis, MO) was added. After incubation for 5 minutes at $65^{\circ} \mathrm{C}$, the samples were processed according to the kit protocol. OnColumn DNase digestion was performed using DNase I digestion kit (Sigma-Aldrich, St. Louis, MO) to remove trace amounts of DNA. 


\section{4. cDNA synthesis and PCR amplification}

\subsection{1. cDNA synthesis}

cDNA was synthesized from total RNA (100 ng) using Superscript III reverse transcriptase () according to the manufacturer's instructions in a total volume of $15 \mu l$. First, $1 \mu l$ of ha $(50 \mu \mathrm{M}), 100 \mathrm{ng}$ total RNA, and $13 \mu l$ of nuclease-free water were added to a nuclease-free microcentrifuge tube. The mixture was heated at $65^{\circ} \mathrm{C}$ for 5 minutes in a heat block and then incubated on ice for 1 minute. Then, $4 \mu l$ of $5 \mathrm{X}$ First-Strand Buffer, $1 \mu l$ of $0.1 \mathrm{M}$ DTT, $1 \mu l$ RNaseOUT, and $1 \mu l$ of Superscript III RT (200 units/ $\mu l$ ) were then added. The tubes were gently pipette-mixed and incubated at $50{ }^{\circ} \mathrm{C}$ for 50 minutes then $70{ }^{\circ} \mathrm{C}$ for 15 minutes.

\subsection{2. $q P C R$ amplification and analysis}

Quantitative PCR was performed using iQ SYBR Green Supermix (Bio-Rad), $1 \mu \mathrm{L}$ sense primer, $1 \mu \mathrm{L}$ antisense primer, $0.4 \mu \mathrm{L}$ Taq DNA polymerase $\left(5 \mathrm{U}^{-1} \mathrm{~L}^{-1}\right)$, and $2 \mu \mathrm{L}$ of cDNA for a total volume of $20 \mu \mathrm{L}$. The amplification conditions were 3 minutes at $95^{\circ} \mathrm{C}, 39$ cycles of 15 seconds at $95{ }^{\circ} \mathrm{C}$ and 1 minute at $60^{\circ} \mathrm{C}$. The primers used for all target genes (Table 2) were designed based on sequences obtained from the NCBI database, and those used in previous studies (Wiersma, Zhang, Lu, Quail, \& Toivonen, 2007). Mdactin and MdUBI were used as reference genes. The target gene expression was normalized to that of the reference genes according to the $2-\Delta \Delta \mathrm{CT}$ method. Samples from Day 0 were assigned an arbitrary quantity of " 1 " and used for calculating the relative expression level of the target gene. The CT values were obtained from 2 biological replicates and within each replicate, each data point is the mean value obtained from qPCR reaction performed in triplicate from a pooled sample of six fruit. 
Table 2. Gene specific primers used for this study

\begin{tabular}{|c|c|c|}
\hline Genes & Primers & Sequences $\left(5^{\prime}-3^{\prime}\right)$ \\
\hline \multirow[t]{2}{*}{$M d A C S 1$} & ACS1-F & СTCСTCСTTTCCTTCGTTGA \\
\hline & ACS1-R & ACCATGTCGTCGTTGGAGTAG \\
\hline \multirow[t]{2}{*}{$M d A C S 3$} & ACS3-F & TGAGTCAAGCAACCCATCTG \\
\hline & ACS3-R & АATTTGCCATTGCCTTTCTG \\
\hline \multirow[t]{2}{*}{$M d A C O 1$} & ACO1-F & GTTCTACAACCCAGGCAACG \\
\hline & ACO1-R & TCTCAGAGCTCAGGCAGTTG \\
\hline \multirow[t]{2}{*}{$M d A C O 2$} & ACO2-F & TCGGACGGAACCAGAATG \\
\hline & $\mathrm{ACO} 2-\mathrm{R}$ & СTCCTTGGCTTGGAATTTGA \\
\hline \multirow[t]{2}{*}{$M d A F S$} & AFS-F & GCTTCCATCACACCGCAGAG \\
\hline & AFS-R & CCCAGATTTGCCCACCACTTG \\
\hline \multirow[t]{2}{*}{$M d U B I 2$} & UBI2-F & TTGATCTTTGCTGGGAAACAG \\
\hline & UBI2-R & САССАССАТСАТТСААСАСС \\
\hline \multirow[t]{2}{*}{$M d P D I 1$} & PDI1-F & TGCAAATCCCTTGCTCCTAC \\
\hline & PDI1R & СССТССТTGTTGTTCTTTGG \\
\hline
\end{tabular}

\subsection{Statistical analysis}

The experiment used a completely randomized design with three replicates (6 apples per replicate) of three treatment groups (control, $310 \mathrm{~Gy}$, and $1000 \mathrm{~Gy}$ ). Data sets were tested, and statistical analyses was performed using RStudio Version 1.1.456 (RCoreTeam, 2015). The mean, standard deviation, and graphs were obtained using Microsoft Excel (Microsoft 2016). ANOVA was used for comparison of mean amplification levels among different treatments. Significant differences were tested using a Tukey test for post hoc testing to determine which gene produced significantly different mean amplification levels. $P$-values below 0.05 were considered statistically significant $(\mathrm{P}<0.05)$. 


\section{Results}

4.1. Effect of x-ray irradiation on ACC oxidase enzyme activity

On day 0 , levels of ACC oxidase were low and not different across treatments $(\mathrm{P}<0.05)$ (Fig. 5). Enzyme activity was highest on day 97 with the activity of the control samples increasing seven-fold as compared to day 7. The irradiated samples also exhibited increased enzyme activity, however irradiation seemed to dampen the increase. The 310 Gy samples showed 5-fold increase and the 1000 Gy exhibited a 3-fold increase as compared to day 7. Activity of the enzyme decreased on day $187(\mathrm{P}<0.05)$ for all the samples, with irradiated samples continuing to exhibit lower enzyme activity as compared to the control.

$$
\text { Control } \quad 310 \mathrm{~Gy} \square 1000 \mathrm{~Gy}
$$

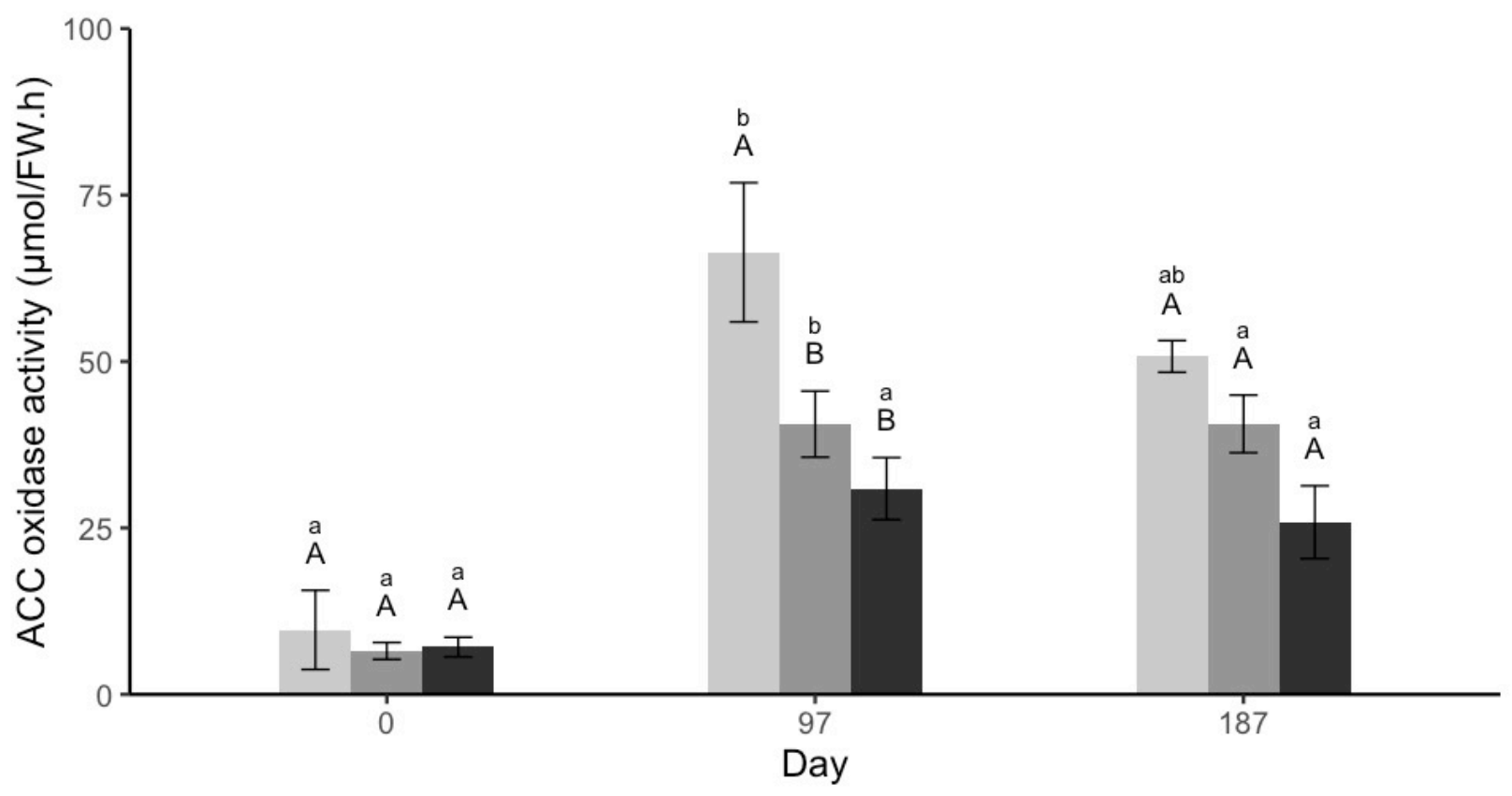

Figure 5. Effect of irradiation (310 and 1000 Gy) on the ACC oxidase (ACO) activity of 'Granny Smith' apples stored for 90 or 180 days at $0-1{ }^{\circ} \mathrm{C}$ followed by seven days of room temperature storage. Results are represented as mean values of three biological replicates and the error bars show the standard deviations. The letters A,B,C show differences due to treatment on 
the given day and the letters a,b,c show differences during storage for any given treatment $(\mathrm{P}<0.05)$

4.2. Effects of X-ray irradiation treatment on the expression of ACS1, ACO1 and ACO2 during postharvest ripening of apple fruit

A

Control $\quad 310 \mathrm{~Gy} \square 1000 \mathrm{~Gy}$

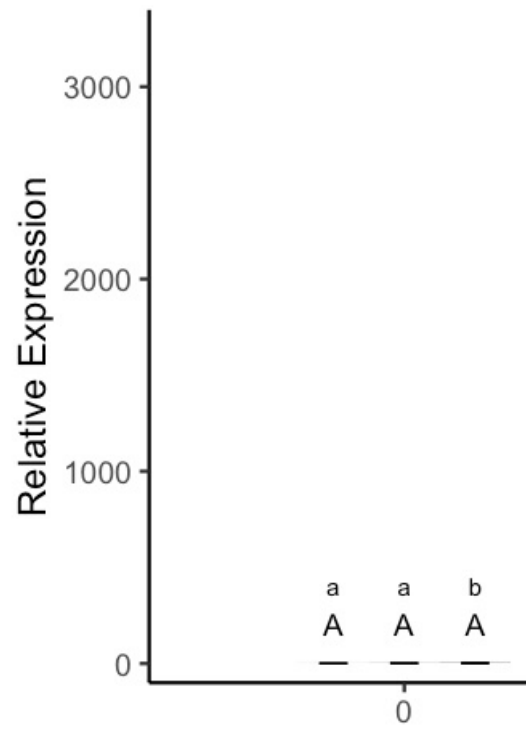

B
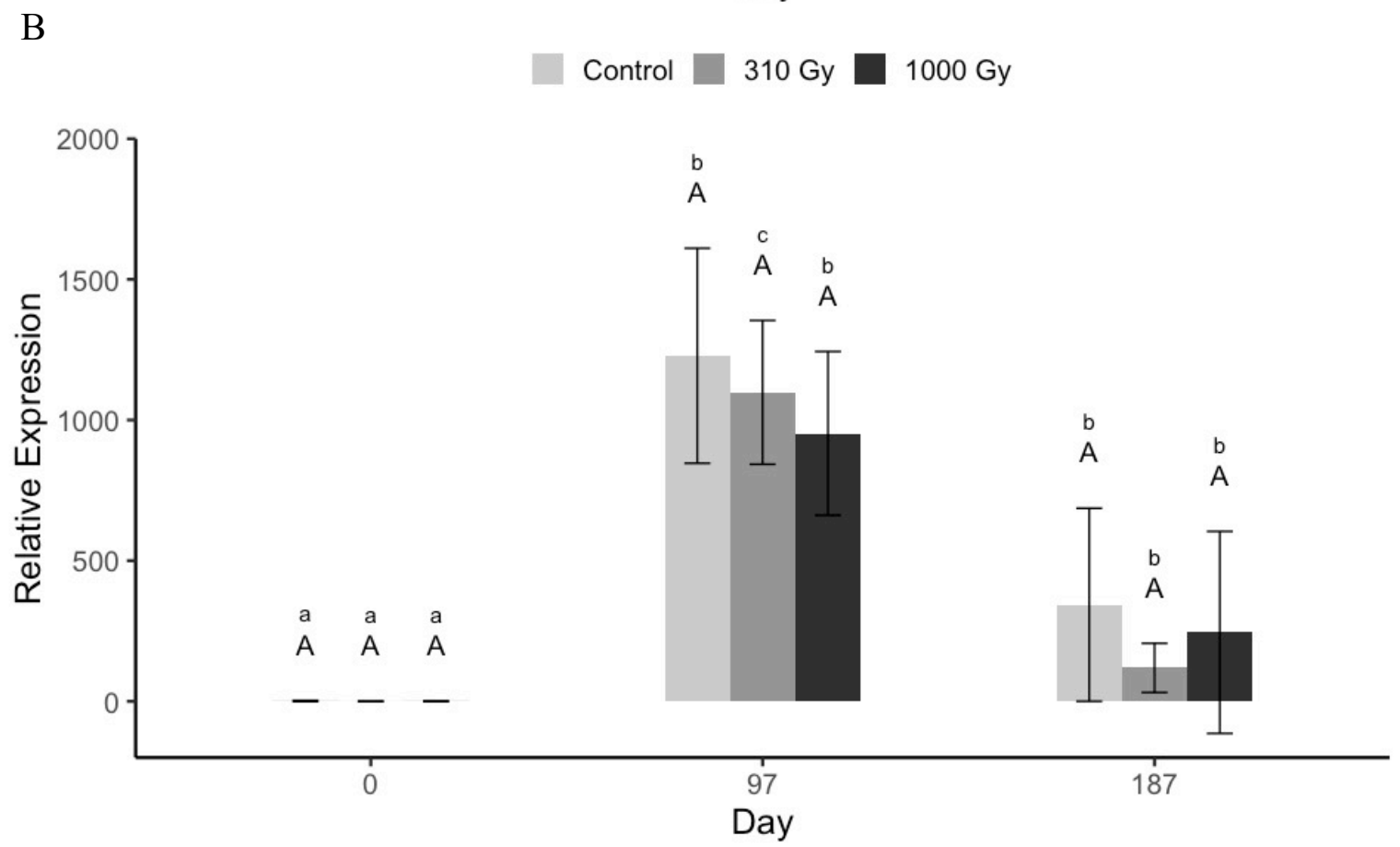


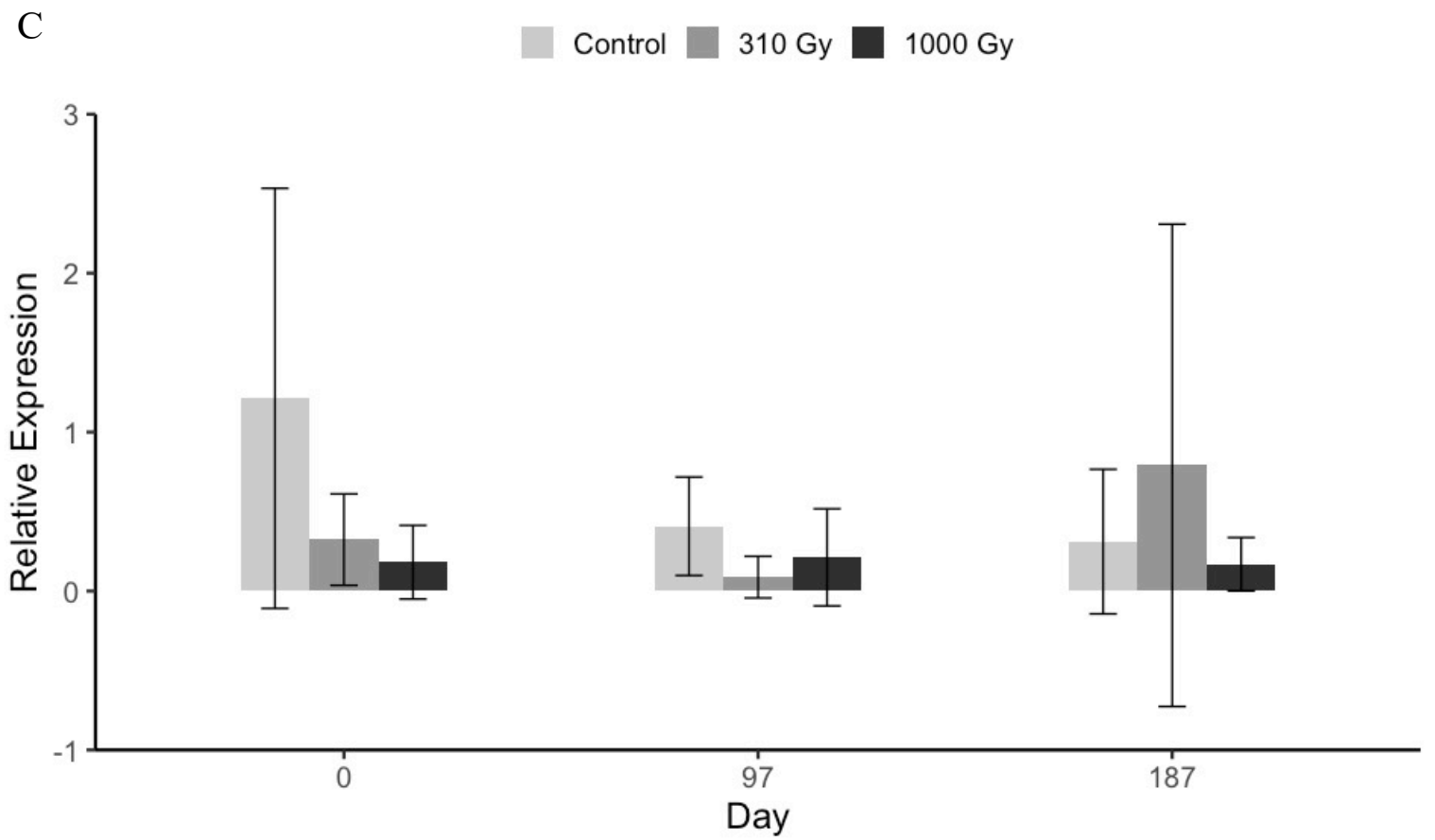

Figure 6. Effect of irradiation on the expressions of Granny Smith ethylene biosynthesis genes, $\operatorname{MdACS} 1$ (A), MdACO1 (B), and MdACO2 (C) stored for 90 or 180 days at $0-1{ }^{\circ} \mathrm{C}$ followed by seven days of room temperature storage. The y axis represents the relative fold difference of mRNA levels and was calculated using a modified 2-DDCt formula (Wan and Wilkins, 1994) with MdPDI as reference. Results are represented as mean values of three biological replicates and the error bars show the standard deviations. Samples from Day 7 (assigned an arbitrary quantity of " 1 ") were used as a calibrator to calculate relative gene expression. The letters A,B,C show differences due to treatment on the given day and the letters a,b,c show differences during storage for any given treatment $(\mathrm{P}<0.05)$.

The control and irradiated samples for ACS1 and ACO1 showed significant expression at day 97 and 187 compared to day 0. ACS1 and ACO1 showed a 2341-fold and 1250-fold expression increase, respectively in control fruit from day 0 to day 97 (Fig. 6a and 6b), followed by day 187. In contrast, ACO2 expression did not change during storage and no statistical 
difference was observed within treatments (Fig. 6c) The expression of ACS1 was down regulated by irradiation treatment at day 97 of storage compared to control fruit while irradiation had no significant effect on ACO1 expression (Fig. 6a and 6b). The expression of ACS1 in 310 Gy irradiated fruit was 1366-fold lower than that in the control fruit at day 97, and $1000 \mathrm{~Gy}$ had more significant reduction on ACS1 expression at day 97 compared to the control. Irradiation did not have a significant effect on expression at 187 days compared to the control. ACS3 expression was unable to be quantified for the samples.

4.3. Effects of $x$-ray irradiation treatment on the expression of $\alpha$-farnesene synthase gene AFS during postharvest ripening of apple fruit

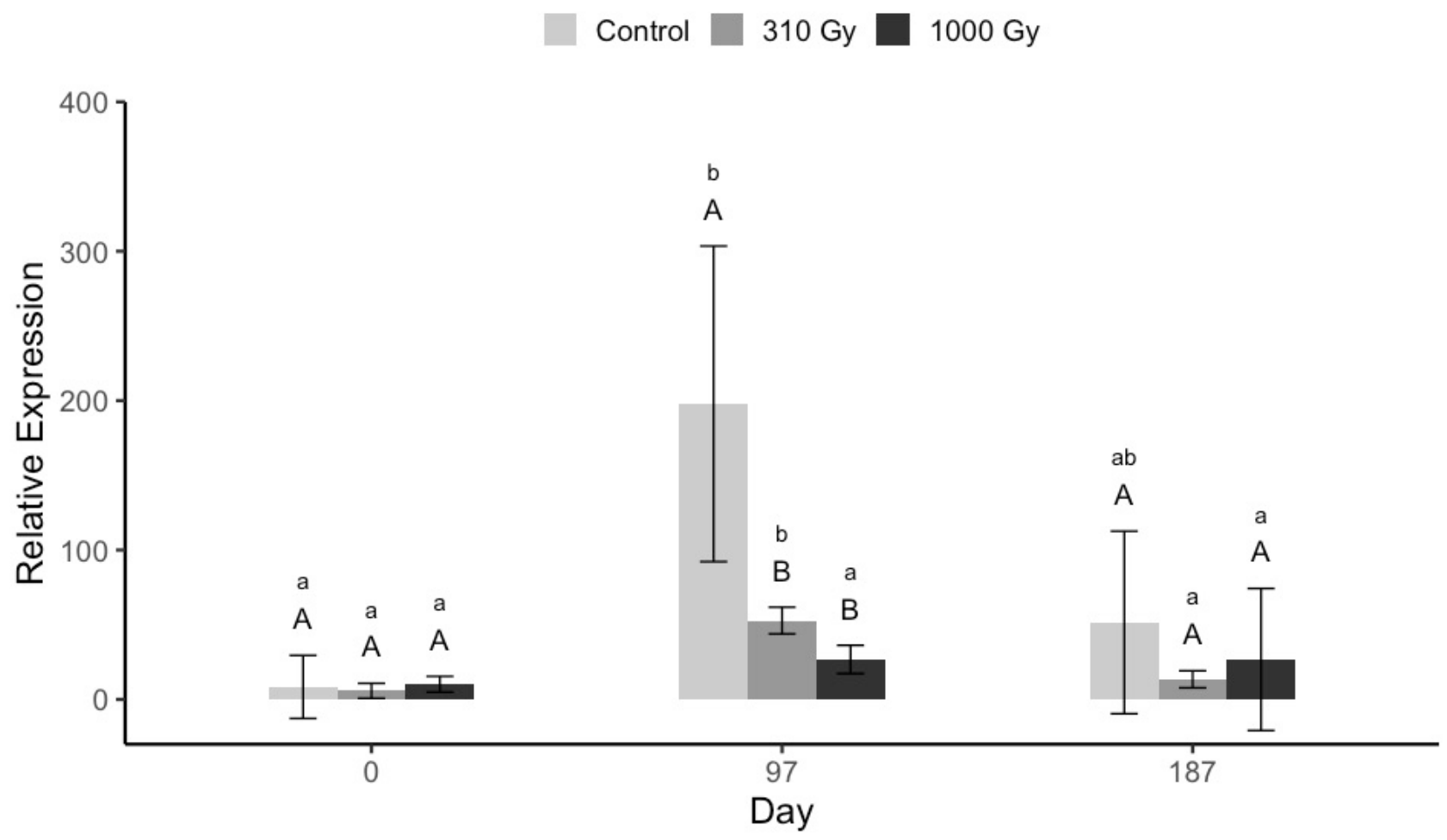

Figure 7. Effect of irradiation on the expressions of Granny Smith $\alpha$-farnesene synthase gene, MdAFS, stored for 90 or 180 days at $0-1{ }^{\circ} \mathrm{C}$ followed by seven days of room temperature storage. The y axis represents the relative fold difference of mRNA levels and was calculated using a modified 2-DDCt formula (Wan and Wilkins, 1994) with MdPDI as reference. Results 
are represented as mean values of three biological replicates and the error bars show the standard deviations. Samples from Day 7 (assigned an arbitrary quantity of "1") were used as a calibrator to calculate relative gene expression. The letters $\mathrm{A}, \mathrm{B}, \mathrm{C}$ show differences due to treatment on the given day and the letters a,b,c show differences during storage for any given treatment $(\mathrm{P}<0.05)$.

At day 0 , levels of $\alpha$-farnesene synthase were low in all samples. In control fruit, $\alpha$ farnesene synthase (AFS) expression showed a 189-fold increase from day 0 to 97 and a subsequent 146-fold reduction at day 187 (Fig. 7). Irradiated fruit, however, exhibited a much smaller increase at day 97. No difference was observed between the control and irradiated fruit at day $187(\mathrm{P}>0.05)$.

\section{Discussion}

\subsection{ACC oxidase enzyme activity and ethylene production}

\subsubsection{ACC oxidase activity and fruit ripening}

ACC oxidase is a key enzyme in the ethylene biosynthesis pathway as it catalyzes the final step of ethylene biosynthesis. ACC oxidase activity and ethylene levels were low on day 7 (data not shown) suggesting that the apples were in a pre-climacteric stage. After 90 days of cold storage, when the apples were warmed at room temperature for seven days, ACC oxidase activity increased by seven-fold $(\mathrm{P}<0.05)$ in the control apples suggesting that the apples went into a climacteric state (Fig. 8). Similarly, ethylene levels also increased significantly (5-fold). At day 187, ACC oxidase and ethylene production decreased suggesting that the apples were beginning to undergo senescence (Iqbal et al., 2017) (Fig. 8). 


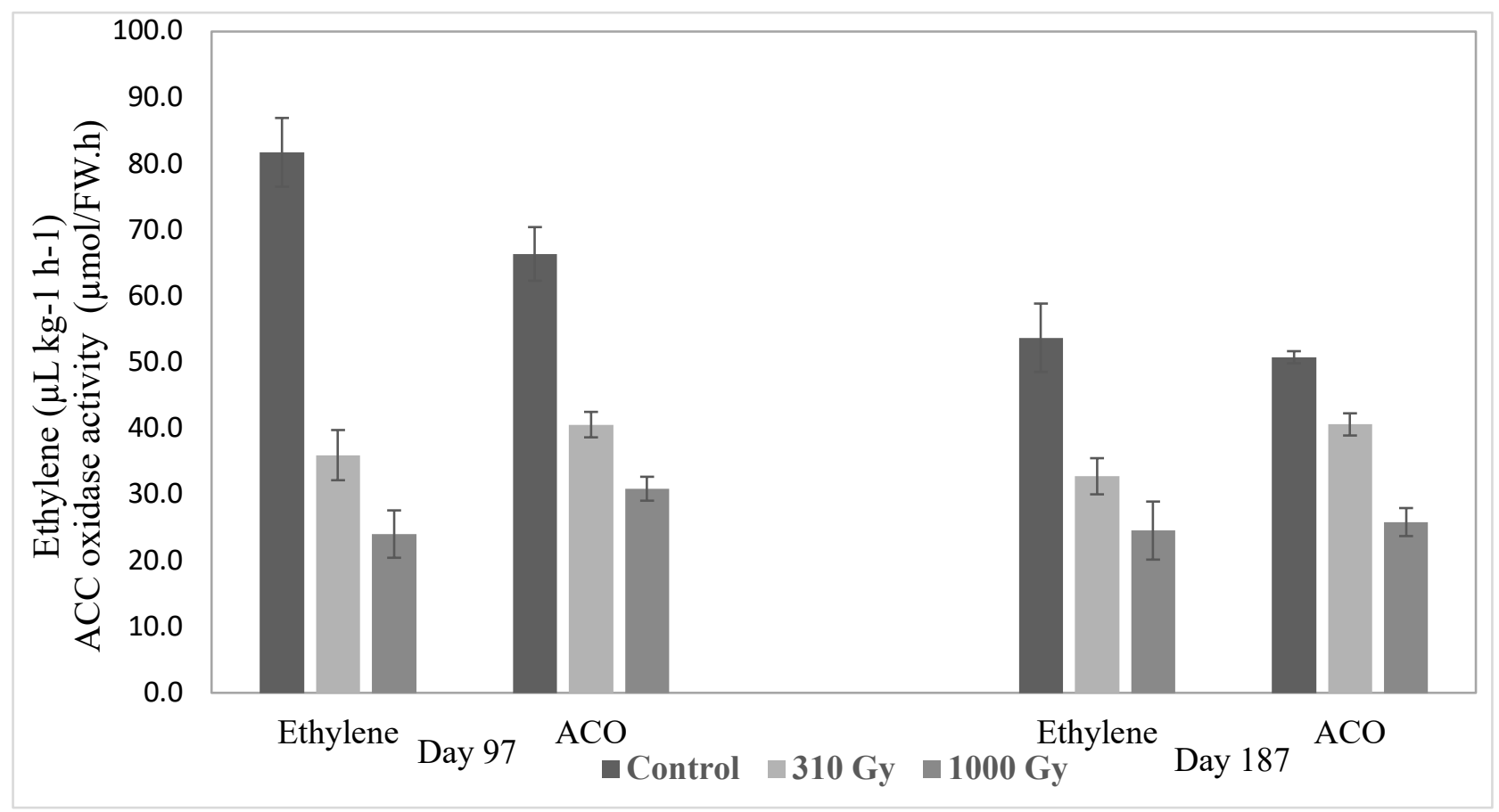

Figure 8. Ethylene production, and ACC oxidase (ACO) activity in 'Granny Smith' apples irradiated (310 Gy, $1000 \mathrm{~Gy})$ and control, stored for 90 and 180 days at $0-1^{\circ} \mathrm{C}$ followed by 7 days at room temperature. Results are represented as mean values of three biological replicates and standard errors are represented as error bars.

\subsubsection{Effect of irradiation on ACC oxidase activity and ethylene production}

Irradiation significantly inhibited ACC oxidase activity and ethylene production. Ethylene production and enzyme activity remained constant from day 97 to 187 among the irradiated samples while they were reduced (Fig. 5 and Fig 8). Previous studies have observed that irradiation reduces ethylene production in apples (Fan et al., 2001; Fan \& Mattheis, 2001; Michael, 2019) and other studies have linked reduced ethylene production to a decrease in ACC oxidase activity in irradiated fruit (D'Innocenzo \& Lajolo, 2001; Michael, 2019; Zeng, Luo, Xie, \& Feng, 2015). 
Fruits treated with ethylene inhibitor 1-MCP showed similar ACC oxidase enzyme activity to our results. Pears treated with 1-MCP before cold storage had significantly reduced ACC oxidase activity after 105 and 180 days of storage compared to untreated pears (Villalobos-Acuna et al., 2011). Villalobos-Acuna and others (1997) also observed a moderated recovery of ethylene production at 180 days of storage paralleled with an increase in ACC oxidase activity at day 180 for 1-MCP treated pears. The recovery of ACC oxidase activity and thus increase in ethylene production at day 180 following 1-MCP treatment is believed to be due to apple fruit's ability to form new ethylene receptors (Zhou et al., 2017). This phenomenon has not been observed with irradiation, as both ACC oxidase activity and ethylene production did not show a recovery from day 97 to day 187 (Olabode, 2019). This suggests that irradiation does not affect ethylene receptors but instead, directly affects ACC oxidase enzyme activity and expression (Beaulieu, D'Aprano, \& Lacroix, 2002; Egea, Martinez-Madrid, Sanchez-Bel, Murcia, \& Romojaro, 2007). Ethylene production is thought to be a membrane-dependent process as ACC oxidase is a membrane-bound enzyme (Ramassamy, Olmos, Bouzayen, Pech, \& Latche, 1998). Therefore, the observed reduction of ACC oxidase enzyme activity in irradiated fruit could also be a result of irradiation-induced membrane damage. Membrane damage caused by irradiation can result in breakage of the bond between the ACC oxidase enzyme and the membrane, leading to reduced ACC oxidase activity and consequently, lower ethylene production (Egea et al., 2007). Irradiation can also affect enzyme structure. Mounter and others (1960), observed that changes in the secondary and tertiary structures of a protein caused by ionzing irradiation can result in altered enzyme activity. While membrane damage and impact on the structure of the enzyme may lead to a decrease in ACC oxidase activity, the more likely cause is the change in gene expression after irradiation (Gudkov, Grinberg, Sukhov, \& Vodeneev, 2019). 


\subsection{Expression of ethylene biosynthesis gene in Granny Smith apples}

Ethylene synthesis during fruit maturation is divided up into two systems, System 1 and System 2 (Varanasi et al., 2011). System 1 of ethylene biosynthesis maintains a basal level of ethylene production before the start of ripening of fruit while system 2 occurs in fruit after ethylene production rises significantly and they begin to ripen (Binnie \& McManus, 2009; Varanasi et al., 2011). Ethylene biosynthesis is catalyzed by ACC synthase and ACC oxidase, two enzymes that are encoded by multi-gene families (Varanasi et al., 2011). 19 ACS genes have been identified with 6 (ACS1, 3, 6, 7, 8 and 9) being expressed in fruit during ripening (T. Li et al., 2013). Of the six ACC synthase genes, ACS1 and ACS3 are expressed specifically in 'Granny Smith' apples (Asif et al., 2009). Three ACC oxidase genes (ACO1, ACO2 and ACO3) have been reported in apples with varying levels of expression during system 1 and 2 (Wiersma et al., 2007). All three ACC oxidase genes are expressed in 'Granny Smith' apples (Asif et al., 2009; Binnie \& McManus, 2009). In our study, the expressions of ACS1, ACO1 and ACO2 were detected in 'Granny Smith' apples, but ACS3 expression was not detected (data not shown). ACS3 expression is believed to be part of system 1 ethylene production as a continuous increase in expression is seen starting as early as 6 weeks before harvest and continuing to increase until fruit is harvested, after which point little to no accumulation is observed (Binnie \& McManus, 2009; T. Li et al., 2013; Wiersma et al., 2007). Additionally, ASC3 expression is cultivar dependent (Binnie \& McManus, 2009; T. Li et al., 2013).

\subsubsection{ACC synthase gene expression}

ACS1 gene was not expressed in control or irradiated fruit stored at room temperature for seven days after harvest (Fig. 6). Similarly, Li and Tan (2013) did not observe ACS1 gene expression until 5 days after apples had been harvested. ACS1 expression is only observed 
during the late ripening stages of fruit development after a sudden increase in ethylene production that correspond to system 2 ethylene synthesis (Varanasi et al., 2011). This is evident by multiple studies that have observed a lack of ACS1 expression in immature apple fruit and a sudden increase in ACS1 expression many days after harvest when fruit have become climacteric (J. Li, Zhu, \& Yuan, 2010; Tan, Li, \& Wang, 2013; Wiersma et al., 2007). ACS1 activity is believed to be the critical measure for ethylene production (Wiersma et al., 2007). When ACS1 was silenced, apple fruit ethylene production was significantly reduced compared to the control (Dandekar et al., 2004). Furthermore, Tan and others (2013) observed that as fruit ripening continued, increase in ACS1 expression paralleled increasing ethylene production. Likewise, our results showed a significant increase in ACS1 expression at day 97 for control fruit (Fig. 6) which coincided with increased ethylene production (Olabode, 2019).

In contrast, $\mathrm{ACS} 3$ expression is thought to be a function of system 1 ethylene production as its expression is observed as early as 6 weeks before harvest and expression is minimal after ACS1 expression is observed (T. Li et al., 2015; T. Li et al., 2013; Varanasi et al., 2011; Wiersma et al., 2007). When apples were treated with Ethephon (plant growth regulator to promote ripening), expression of ACS1 was significantly enhanced while ASC3 expression was inhibited (Tan et al., 2013). The inhibition of ACS3 expression by Ethephon suggests that an increase in ethylene results in a negative feedback regulation of ACS3 (Tan et al., 2013). Tatsuki and others (2007) further support this notion as an inhibition of ACS3 was observed after fruits were also treated with ethylene. ACS3 expression precedes the expression of ACS1, ACO1 and ACO2 in apple fruit and is response for low levels of ethylene production during the early growth stages of plant growth (A. Wang et al., 2009). Furthermore, ACS3 expression is suppressed when fruit begin to ripen after harvest and postharvest treatment of fruit with 
ethylene inhibits ACS3 expression compared to control fruit (Tatsuki et al., 2007; Wiersma et al., 2007). Expression of ACS3 is also cultivar dependent. Wiersma (2007) saw that ACS3 expression was observed three weeks before harvest and started to decrease after harvest for 'Golden Delicious' apples while expression for 'Sunrise' apples was observed four weeks before harvest and still showed significant expression after harvest (Wiersma et al., 2007).

\subsubsection{ACC oxidase gene expression}

The expression of ACO1 has also been correlated with the sudden burst of ethylene in climacteric fruit. Comparable to ACS1, ACO1 gene expression is also seen to significantly increase during apple fruit ripening with greater expression occurring when apples are treated with exogenous ethylene compared to control (X. Yang et al., 2013). Although we did not observe a significant difference in expression between treatments for ACO1, there was a significant increase in expression from harvest to day 97 when the fruit had ripened (Fig. 6).

The role of $\mathrm{ACO} 2$ in ethylene synthesis and fruit ripening has yet to be fully explored and is still unclear. Wiersma and others (2007) found that the gene expression of ACO2 during ripening was cultivar dependent. ACO2 exhibited a 12-fold decrease in 'Sunrise' while 'Golden Delicious' apples had a 4-fold increase. Yang and others (2013) did not observe any significant changes in $\mathrm{ACO} 2$ after treatment with ethylene and ethylene inhibitor 1-MCP. ACO2 expression has also been found to occur predominately in young fruit tissue (Binnie \& McManus, 2009). Although no definitive answer has been found on the role of ACO2 involvement in ethylene synthesis, we observed that irradiation did not affect the expression of ACO2 at any of the three time points (Fig. 6). 


\subsection{Influence of Ionizing Irradiation on gene expression}

In our experiment, irradiation suppressed the expression of ACS1 $(\mathrm{P}<0.05)$ while not significantly affecting the expression of $\mathrm{ACO} 1$ and $\mathrm{ACO} 2$. Reduced ethylene production coincided with the suppression of ACS1 gene expression, but not ACO1 and ACO2 gene expression. These results indicate that irradiation-induced suppression of gene expression in ACS1 may affect ethylene production. There are no studies that have evaluated the impact of low dose gamma, e-beam, or x-ray treatment on gene expression of ripening enzymes, but studies evaluating the impacts of UV irradiation might provide some explanations. UV-C treatment in tomatoes resulted in slower color development compared to control and delayed ripening despite an initial increase in ethylene production and ACO1 expression (Severo et al., 2015). The increase in ethylene is due to UV-C acting as a stressor and plants generally produce ethylene under stress. Delayed ripening resulted in lower levels of carotenoids which are the main compounds responsible for tomatoes color (Severo et al., 2015). The effect of UV-C treatment on coloration may be due to its interference with carotenoid metabolism genes which were both up-regulated and down-regulated after UV-C treatment (Liu, Cai, Han, \& Ying, 2011). UV-C treated cherry tomatoes also displayed altered gene expression of PME 2.1, PGcat and Cel1, three genes encoding for cell wall degrading enzymes pectin methylesterase (PME), polygalacturonase (PG), and cellulase in cherry tomatoes. Suppression of these genes coincided with suppressed enzyme activity resulting in delayed fruit softening (Bu, Yu, Aisikaer, \& Ying, 2013).

A genetic response after irradiation in plants can occur immediately or weeks to months after irradiation (Gudkov et al., 2019). Plant's immediate response to irradiation tends to be similar to their response to an external stimulus, while a delayed response is caused by irradiation-induced 
damage to DNA, lipids and proteins of plant cells which disrupts normal physiological processes (Gudkov et al., 2019). Ionizing irradiation is considered an environmental stressor for plants and has been reported to cause DNA damage (Gudkov et al., 2019). Ionizing irradiation results in the formation of reactive oxygen species (ROS) which are highly reactive free radicals formed by radiolysis of water. ROS react with various types of macromolecules, including lipids, proteins, and DNA (Esnault, Legue, \& Chenal, 2010). DNA is the most preferable macromolecule attacked by ROS; and DNA damage caused by irradiation is considered the main cause in the destruction of cell function and cell death (Gill, Anjum, Gill, Jha, \& Tuteja, 2015; Gudkov et al., 2019). $70-80 \%$ of DNA damage is cause by radiolysis formed ROS while $20-30 \%$ is cause by direct deposit of irradiation energy on DNA molecules (Gudkov et al., 2019). Plants are able to repair most of the damage; however, repair errors are prone to occur which can lead to various DNA alterations that can be carried on through RNA transcription and possibly result in the translation of non-functional proteins (Gill et al., 2015; Gudkov et al., 2019). Irradiation usually results in the genetic modification of various physiological processes such as hormone response, and development (Gudkov et al., 2019; Kovalchuk, Molinier, Yao, Arkhipov, \& Kovalchuk, 2007).

Irradiation has been shown to induce and suppress the expression of plant genes in different physiological states. Hoeck and others (2017) found that exposing L. minor plants (floating freshwater aquatic plant) with an external dose rate of up to $1500 \mathrm{mGy} \mathrm{h}^{\wedge}-1$ of gammairradiation at a dose range of $25 \mathrm{mGy}$ to $450 \mathrm{mGy}$ for seven days affected the expression levels of 3079 genes out of 3352 genes. These reported changes are a result of irradiation affecting physiological process in plants. Changes in physiological processes after irradiation are mediated by signaling cascades which activate or inactivate various transcription factors. Transcription 
factors are proteins that turn genes "on" or "off", directly effecting gene expression (Gudkov et al., 2019). Studies have shown that ionizing irradiation affects many signal transduction genes (Kim et al., 2011; Van Hoeck et al., 2017).

\subsection{Reduction of superficial scald and $\alpha$-farnesene synthase gene expression} Irradiation mediated reduction of superficial scald (Olabode, 2019) correlated with the reduction in expression of $\alpha$-farnesene synthase gene (AFS). AFS, the last enzyme in the $\alpha$-farnesene pathway, is closely linked with ethylene production and subsequent accumulation of $\alpha$-farnesene in apples (Lurie et al., 2005; Tsantili, Gapper, Arquiza, Whitaker, \& Watkins, 2007). Little information is available about the response of AFS to irradiation, however many studies have investigated the effect of 1-MCP an ethylene inhibitor on AFS gene expression during storage. Pechous and others (2005) observed that 1-MCP treatment reduced ethylene production and suppressed $\alpha$-farnesene and AFS expression levels, greatly preventing scald compared to control Law Rome apples. Similarly, Tsantili and others (2007) observed that 1-MCP treatment gradually decreased internal ethylene concentrations (IECs) and delayed accumulation of $\alpha$ farnesene in scald-susceptible Cortland and Law Rome apples. The expression of AFS was initially suppressed by 1-MCP treatment however, a return in expression was observed after 1015 weeks (Tsantili et al., 2007). Pechous and others (2005) observed similar results as 1-MCP induced $\alpha$-farnesene reduction in Law Rome apples was overcome after 20 weeks of storage corresponding to a rise in IEC and AFS expression after 20 weeks of storage. Similar to these studies, our results showed that irradiation mediated inhibition of $\alpha$-farnesene synthase expression at day 97 correlates with reduction of ethylene production and lack of observable scald development (Fig. 7 and Fig. 8) (Olabode, 2019). Irradiated and control apples did not significant increase in AFS expression at day 187 compared to harvest (Fig. 7). This is likey due 
to minimal AFS production occurring in the apples after long storage times (Lurie et al., 2005). Irradiation appears to have a long-lasting inhibition of AFS expression and superficial scald incidence compared to 1-MCP treatment. Therefore, irradiation treatment can be a possible nonchemical alternative to 1-MCP to block ethylene biosynthesis and prevent superficial scald for apples stored for extended periods of time. 


\section{Conclusion}

Irradiation affected the expression of ethylene biosynthesis gene ACS1 and, however it had no effect on the expression of ACS3, ACO1 and ACO2 genes. Suppression of ACS1 gene expression correlated with decreased activity of ACC oxidase and ethylene production. Reduced ethylene production coincided with a significant decrease in $\alpha$-farnesene synthase gene expression, resulting in lower $\alpha$-farnesene concentrations, and ultimately diminished superficial scald. Reduced gene expression as a result of irradiation may be caused by DNA damage, however further investigations on the mechanism of how irradiation induces changes to individual genes in postharvest fruit are needed. It would also be interesting to determine if irradiation can decrease incidence of other ethylene-mediated defects, and if similar responses are evident in other fruit. 


\section{References}

Abdallah, A. Y., Gil, M. I., Biasi, W., \& Mitcham, E. J. (1997). Inhibition of superficial scald in apples by wounding: changes in lipids and phenolics. Postharvest Biology and Technology, 12(3), 203-212. doi:10.1016/s0925-5214(97)00060-4

Aschemann-Witzel, J., Varela, P., \& Peschel, A. O. (2019). Consumers' categorization of food ingredients: Do consumers perceive them as 'clean label' producers expect? An exploration with projective mapping. Food Quality and Preference, 71, 117-128. doi:10.1016/j.foodqual.2018.06.003

Asif, M. H., Pathak, N., Solomos, T., \& Trivedi, P. K. (2009). Effect of low oxygen, temperature and 1-methylcyclopropene on the expression of genes regulating ethylene biosynthesis and perception during ripening in apple. South African Journal of Botany, 75(1), 137144. doi:10.1016/j.sajb.2008.09.002

Beaulieu, M., D'Aprano, G., \& Lacroix, M. (2002). Effect of dose rate of gamma irradiation on biochemical quality and browning of mushrooms Agaricus bisporus. Radiation Physics and Chemistry, 63(3-6), 311-315. doi:10.1016/s0969-806x(01)00518-7

Binnie, I. E., \& McManus, M. T. (2009). Characterization of the 1-aminocyclopropane-1carboxylic acid (ACC) oxidase multigene family of Malus domestica Borkh. Phytochemistry, 70(3), 348-360. doi:10.1016/j.phytochem.2009.01.002

Blakey, R. (2014). Superficial Scald Management in Apples.

Blankenship, S. M., \& Dole, J. M. (2003). 1-methylcyclopropene: a review. Postharvest Biology and Technology, 28(1), 1-25. doi:10.1016/s0925-5214(02)00246-6

Bleecker, A. B., \& Kende, H. (2000). Ethylene: A gaseous signal molecule in plants. Annual Review of Cell and Developmental Biology, 16, 1-+. doi:10.1146/annurev.cellbio.16.1.1 
Bris, M. (2003). Hormones in Growth and Development: Encyclopedia of Rose Science

Bu, J., Yu, Y., Aisikaer, G., \& Ying, T. (2013). Postharvest UV-C irradiation inhibits the production of ethylene and the activity of cell wall-degrading enzymes during softening of tomato (Lycopersicon esculentum L.) fruit. Postharvest Biology and Technology, 86, 337-345. doi:10.1016/j.postharvbio.2013.07.026

Bulens, I., Van de Poel, B., Hertog, M. L. A. T. M., Cristescu, S. M., Harren, F. J. M., De Proft, M. P., . . Nicolai, B. M. (2014). Dynamic changes of the ethylene biosynthesis in 'Jonagold' apple. Physiologia Plantarum, 150(2), 161-173. doi:10.1111/ppl.12084

Bulens, I., Van de Poel, B., Hertog, M. L. A. T. M., De Proft, M. P., Geeraerd, A. H., \& Nicolai, B. M. (2011). Protocol: An updated integrated methodology for analysis of metabolites and enzyme activities of ethylene biosynthesis. Plant Methods, 7. doi:10.1186/17464811-7-17

Calvo, G. (2010). Antioxidant use in apple and pear storage part 1 - regulatory situation Retrieved from http://postharvest.tfrec.wsu.edu/REP2010C.pdf

CDC. (2019). Diphenylamine. Retrieved from https://www.cdc.gov/niosh/npg/npgd0240.html Costa, F., Stella, S., Van de Weg, W. E., Guerra, W., Cecchinel, M., Dalla Via, J., ... Sansavini, S. (2005). Role of the genes Md-ACO1 and Md-ACS1 in ethylene production and shelf life of apple (Malus domestica Borkh). Euphytica, 141(1-2), 181-190. doi:10.1007/s10681-005-6805-4

D'Innocenzo, M., \& Lajolo, F. M. (2001). Effect of gamma irradiation on softening changes and enzyme activities during ripening of papaya fruit. Journal of Food Biochemistry, 25(5), 425-438. doi:10.1111/j.1745-4514.2001.tb00750.x 
Dandekar, A. M., Teo, G., Defilippi, B. G., Uratsu, S. L., Passey, A. J., Kader, A. A., . . James, D. J. (2004). Effect of down-regulation of ethylene biosynthesis on fruit flavor complex in apple fruit. Transgenic Research, 13(4), 373-384.

doi:10.1023/b:trag.0000040037.90435.45

Du, L. N., Song, J., Palmer, L. C., Fillmore, S., \& Zhang, Z. Q. (2017). Quantitative proteomic changes in development of superficial scald disorder and its response to diphenylamine and 1-MCP treatments in apple fruit. Postharvest Biology and Technology, 123, 33-50. doi:10.1016/j.postharvbio.2016.08.005

Egea, M. I., Martinez-Madrid, M. C., Sanchez-Bel, P., Murcia, M. A., \& Romojaro, F. (2007). The influence of electron-beam ionization on ethylene metabolism and quality parameters in apricot (Prunus armeniaca L., cv Bulida). Lwt-Food Science and Technology, 40(6), 1027-1035. doi:10.1016/j.lwt.2006.06.005

Esnault, M.-A., Legue, F., \& Chenal, C. (2010). Ionizing radiation: Advances in plant response. Environmental and Experimental Botany, 68(3), 231-237.

doi:10.1016/j.envexpbot.2010.01.007

Fan, X. T., Argenta, L., \& Mattheis, J. (2001). Impacts of ionizing radiation on volatile production by ripening gala apple fruit. Journal of Agricultural and Food Chemistry, 49(1), 254-262. doi:10.1021/jf0008994

Fan, X. T., \& Mattheis, J. P. (2001). 1-methylcyclopropene and storage temperature influence responses of 'Gala' apple fruit to gamma irradiation. Postharvest Biology and Technology, 23(2), 143-151. doi:10.1016/s0925-5214(01)00119-3

FDA. (2018). Irradiation Treatment Requirements. 21. Retrieved from https://www.law.cornell.edu/cfr/text/7/305.9 
Gill, S. S., Anjum, N. A., Gill, R., Jha, M., \& Tuteja, N. (2015). DNA damage and repair in plants under ultraviolet and ionizing radiations. TheScientificWorldJournal, 2015, 250158-250158. doi:10.1155/2015/250158

Gudkov, S. V., Grinberg, M. A., Sukhov, V., \& Vodeneev, V. (2019). Effect of ionizing radiation on physiological and molecular processes in plants. Journal of Environmental Radioactivity, 202, 8-24. doi:10.1016/j.jenvrad.2019.02.001

Gussman, C. D., Goffreda, J. C., \& Gianfagna, T. J. (1993). Ethylene Production and FruitSoftening Rates in Several Apple Fruit Ripening Variants. Hortscience, 28(2), 135-137.

Hallman, G. J., \& Loaharanu, P. (2016). Phytosanitary irradiation - Development and application. Radiation Physics and Chemistry, 129, 39-45. doi:10.1016/j.radphyschem.2016.08.003

Harb, J., Gapper, N. E., Giovannoni, J. J., \& Watkins, C. B. (2012). Molecular analysis of softening and ethylene synthesis and signaling pathways in a non-softening apple cultivar, 'Honeycrisp' and a rapidly softening cultivar, 'McIntosh'. Postharvest Biology and Technology, 64(1), 94-103. doi:10.1016/j.postharvbio.2011.10.001

Hennessey, M. K., 0.0px, p. p. m. p. p. p., Helvetica\}, f. p., Jeffers, L., 0.0px, p. p. m. p. p. p., Helvetica\}, f. p., \& Nendick, D., KEnFloyd, L. Hansen, J.D.Bailey, W.D.Winborne, IBartels, D. Ramsey, C.Devorshak, C. (2014). Phytosanitary Treatments. In: Springer Netherlands.

Iacovides, S., \& Meiring, R. M. (2018). The effect of a ketogenic diet versus a highcarbohydrate, low-fat diet on sleep, cognition, thyroid function, and cardiovascular health independent of weight loss: study protocol for a randomized controlled trial. Trials, 19 . doi:10.1186/s13063-018-2462-5 
Iqbal, N., Khan, N. A., Ferrante, A., Trivellini, A., Francini, A., \& Khan, M. I. R. (2017). Ethylene Role in Plant Growth, Development and Senescence: Interaction with Other Phytohormones. Frontiers in Plant Science, 8. doi:10.3389/fpls.2017.00475

Ireland, H. S., Gunaseelan, K., Muddumage, R., Tacken, E. J., Putterill, J., Johnston, J. W., \& Schaffer, R. J. (2014). Ethylene Regulates Apple (Malus x domestica) Fruit Softening Through a Dose x Time-Dependent Mechanism and Through Differential Sensitivities and Dependencies of Cell Wall-Modifying Genes. Plant and Cell Physiology, 55(5), 1005-1016. doi:10.1093/pcp/pcu034

Jung, S.-K., \& Watkins, C. B. (2014). Internal ethylene concentrations in apple fruit at harvest affect persistence of inhibition of ethylene production after 1-methylcyclopropene treatment. Postharvest Biology and Technology, 96, 1-6. doi:10.1016/j.postharvbio.2014.04.008

Karagiannis, E., Michailidis, M., Tanou, G., Samiotaki, M., Karamanoli, K., Avramidou, E., ... Molassiotis, A. (2018). Ethylene -dependent and -independent superficial scald resistance mechanisms in 'Granny Smith' apple fruit. Scientific Reports, 8. doi:10.1038/s41598-01829706-x

Kende, H. (1993). Ethylene Biosynthesis. Annual Review of Plant Physiology and Plant Molecular Biology, 44(1), 283-307.

Kim, D. S., Kim, J.-B., Goh, E. J., Kim, W.-J., Kim, S. H., Seo, Y. W., . . Kang, S.-Y. (2011). Antioxidant response of Arabidopsis plants to gamma irradiation: Genome-wide expression profiling of the ROS scavenging and signal transduction pathways. Journal of Plant Physiology, 168(16), 1960-1971. doi:10.1016/j.jplph.2011.05.008 
Kovalchuk, I., Molinier, J., Yao, Y., Arkhipov, A., \& Kovalchuk, O. (2007). Transcriptome analysis reveals fundamental differences in plant response to acute and chronic exposure to ionizing radiation. Mutation Research-Fundamental and Molecular Mechanisms of Mutagenesis, 624(1-2), 101-113. doi:10.1016/j.mrfmmm.2007.04.009

Li, J., Zhu, H., \& Yuan, R. (2010). Profiling the Expression of Genes Related to Ethylene Biosynthesis, Ethylene Perception, and Cell Wall Degradation during Fruit Abscission and Fruit Ripening in Apple. Journal of the American Society for Horticultural Science, 135(5), 391-401.

Li, T., Tan, D., Liu, Z., Jiang, Z., Wei, Y., Zhang, L., . . Wang, A. (2015). Apple MdACS6 Regulates Ethylene Biosynthesis During Fruit Development Involving EthyleneResponsive Factor. Plant and Cell Physiology, 56(10), 1909-1917. doi:10.1093/pcp/pcv111

Li, T., Tan, D., Yang, X., \& Wang, A. (2013). Exploring the apple genome reveals six ACC synthase genes expressed during fruit ripening. Scientia Horticulturae, 157, 119-123. doi:10.1016/j.scienta.2013.04.016

Liu, C., Cai, L., Han, X., \& Ying, T. (2011). Temporary effect of postharvest UV-C irradiation on gene expression profile in tomato fruit. Gene, 486(1-2), 56-64. doi:10.1016/j.gene.2011.07.001

Lurie, S., Lers, A., Shacham, Z., Sonego, L., Burd, S., \& Whitaker, B. (2005). Expression of alpha-farnesene synthase AFS1 and 3-hydroxy-3-methylglutaryl-coenzyme a reductase HMG2 and HMG3 in relation to alpha-farnesene and conjugated trienols in 'Granny Smith' apples heat or 1-MCP treated to prevent superficial scald. Journal of the American Society for Horticultural Science, 130(2), 232-236. 
Massey Jr., L. M., Parsons, G. F., \& Smock, R. M. (1964). Radiation Processing of Foods, Some Effects of Gamma Radiation on Keeping Quality of Apples. J. Agric. Food Chem, 12(3), 268-274. doi:10.1021/jf60133a025

Mditshwa, A., Fawole, O. A., Vries, F., Van Der Merwe, K., Crouch, E., \& Opara, U. L. (2016). Classification of 'Granny Smith' apples with different levels of superficial scald severity based on targeted metabolites and discriminant analysis. Journal of Applied Botany and Food Quality, 89, 49-55. doi:10.5073/jabfq.2016.089.006

Meadows, R. (2013). News overview Researchers develop alternatives to methyl bromide fumigation. California Agriculture, 67(3), 125-127. doi:10.3733/ca.v067n03p125

Michael, B. C. (2019). Physiological Changes Induced by Phytosanitary Irradiation Do Not Affect Sensory Properties of Early and Late-Harvested Gala Apples. Master's thesis, Chapman University.

Mir, N. A., \& Beaudry, R. (1999). Effect of superficial scald suppression by diphenylamine application on volatile evolution by stored Cortland apple fruit. Journal of Agricultural and Food Chemistry, 47(1), 7-11. doi:10.1021/jf9805810

Moggia, C., Moya-Leon, M. A., Pereira, M., Yuri, J. A., \& Lobos, G. A. (2010). Effect of DPA and 1-MCP on chemical compounds related to superficial scald of Granny Smith apples. Spanish Journal of Agricultural Research, 8(1), 178-187. doi:10.5424/sjar/2010081-1157

Mounter, L. A. (1960). Studies of the effects of radiation on enzymes .1. Inactivation of chymotrypsin and chymotrypsinogen by x-rays. Radiation Research, 12(5), 487-494. doi: $10.2307 / 3570970$ 
Olabode, P. (2019). Irradiation as an Alternative to Methyl Bromide Fumigation and Diphenylamine Treatment of 'Granny Smith' Apples. Master's thesis, Chapman University.

Paul, V., \& Pandey, R. (2014). Role of internal atmosphere on fruit ripening and storability-a review. Journal of Food Science and Technology-Mysore, 51(7), 1223-1250. doi:10.1007/s13197-011-0583-x

Pechous, S. W., Watkins, C. B., \& Whitaker, B. D. (2005). Expression of alpha-farnesene synthase gene AFS1 in relation to levels of alpha-farnesene and conjugated trienols in peel tissue of scald-susceptible 'Law Rome' and scald-resistant 'Idared' apple fruit. Postharvest Biology and Technology, 35(2), 125-132. doi:10.1016/j.postharvbio.2004.08.005

Ramassamy, S., Olmos, E., Bouzayen, M., Pech, J. C., \& Latche, A. (1998). 1aminocyclopropane-1-carboxylate oxidase of apple fruit is periplasmic. Journal of Experimental Botany, 49(329), 1909-1915. doi:10.1093/jexbot/49.329.1909

RCoreTeam. (2015). R: A Language and Environment for Statistical Computing. In. Vienna, Austria: R Foundation for Statistical Computing.

Rowan, D. D., Hunt, M. B., Fielder, S., Norris, J., \& Sherburn, M. S. (2001). Conjugated triene oxidation products of alpha-farnesene induce symptoms of superficial scald on stored apples. Journal of Agricultural and Food Chemistry, 49(6), 2780-2787. doi: $10.1021 / \mathrm{jf0015221}$

Rudus, I., Sasiak, M., \& Kepczynski, J. (2013). Regulation of ethylene biosynthesis at the level of 1-aminocyclopropane-1-carboxylate oxidase (ACO) gene. Acta Physiologiae Plantarum, 35(2), 295-307. doi:10.1007/s11738-012-1096-6 
Saltveit, M. E. (1999). Effect of ethylene on quality of fresh fruits and vegetables. Postharvest Biology and Technology, 15(3), 279-292. doi:10.1016/s0925-5214(98)00091-x

Savran, H. E., \& Koyuncu, M. A. (2016). The effects of superficial scald control methods having different effect mechanisms on the scald formation and alpha-farnesene content in apple cv. 'Granny Smith'. Scientia Horticulturae, 211, 174-178.

doi:10.1016/j.scienta.2016.08.023

Severo, J., Tiecher, A., Pirrello, J., Regad, F., Latche, A., Pech, J.-C., . . Rombaldi, C. V. (2015). UV-C radiation modifies the ripening and accumulation of ethylene response factor (ERF) transcripts in tomato fruit. Postharvest Biology and Technology, 102, 9-16. doi:10.1016/j.postharvbio.2015.02.001

Shi, H.-Y., \& Zhang, Y.-X. (2012). Pear ACO genes encoding putative 1-aminocyclopropane-1carboxylate oxidase homologs are functionally expressed during fruit ripening and involved in response to salicylic acid. Molecular Biology Reports, 39(10), 9509-9519. doi:10.1007/s11033-012-1815-5

Tan, D., Li, T., \& Wang, A. (2013). Apple 1-Aminocyclopropane-1-Carboxylic Acid Synthase Genes, MdACS1 and MdACS3a, are Expressed in Different Systems of Ethylene Biosynthesis. Plant Molecular Biology Reporter, 31(1), 204-209. doi:10.1007/s11105012-0490-y

Tatsuki, M., Endo, A., \& Ohkawa, H. (2007). Influence of time from harvest to 1-MCP treatment on apple fruit quality and expression of genes for ethylene biosynthesis enzymes and ethylene receptors. Postharvest Biology and Technology, 43(1), 28-35.

doi:10.1016/j.postharvbio.2006.08.010 
Tsantili, E., Gapper, N. E., Arquiza, J. M. R. A., Whitaker, B. D., \& Watkins, C. B. (2007). Ethylene and alpha-farnesene metabolism in green and red skin of three apple cultivars in response to 1-methylcyclopropene (1-MCP) treatment. Journal of Agricultural and Food Chemistry, 55(13), 5267-5276. doi:10.1021/jf0637751

Van Hoeck, A., Horernans, N., Nauts, R., Van Hees, M., Vandenhove, H., \& Blust, R. (2017). Lemna minor plants chronically exposed to ionising radiation: RNA-seq analysis indicates a dose rate dependent shift from acclimation to survival strategies. Plant Science, 257, 84-95. doi:10.1016/j.plantsci.2017.01.010

Varanasi, V., Shin, S., Mattheis, J., Rudell, D., \& Zhu, Y. (2011). Expression profiles of the MdACS3 gene suggest a function as an accelerator of apple (Malus X domestica) fruit ripening. Postharvest Biology and Technology, 62(2), 141-148.

doi:10.1016/j.postharvbio.2011.05.005

Varela, P., Salvador, A., \& Fiszman, S. (2005). Shelf-life estimation of 'Fuji' apples: Sensory characteristics and consumer acceptability. Postharvest Biology and Technology, 38(1), 18-24. doi:10.1016/j.postharvbio.2005.05.009

Villalobos-Acuna, M. G., Biasi, W. V., Flores, S., Jiang, C.-Z., Reid, M. S., Willits, N. H., \& Mitcham, E. J. (2011). Effect of maturity and cold storage on ethylene biosynthesis and ripening in 'Bartlett' pears treated after harvest with 1-MCP. Postharvest Biology and Technology, 59(1), 1-9. doi:10.1016/j.postharvbio.2010.08.001

Wang, A., Yamakake, J., Kudo, H., Wakasa, Y., Hatsuyama, Y., Igarashi, M., . . Harada, T. (2009). Null Mutation of the MdACS3 Gene, Coding for a Ripening-Specific 1Aminocyclopropane-1-Carboxylate Synthase, Leads to Long Shelf Life in Apple Fruit. Plant Physiology, 151(1), 391-399. doi:10.1104/pp.109.135822 
Wang, K. L. C., Li, H., \& Ecker, J. R. (2002). Ethylene biosynthesis and signaling networks. Plant Cell, 14, S131-S151. doi:10.1105/tpc.001768

Watkins, C. B. (2006). The use of 1-methylcyclopropene (1-MCP) on fruits and vegetables. Biotechnology Advances, 24(4), 389-409. doi:10.1016/j.biotechadv.2006.01.005

Watkins, C. B., Bramlage, W. J., \& Cregoe, B. A. (1995). Superficial Scald of Granny Smith Apples is Expressed as a Typical Chilling Injury. Journal of the American Society for Horticultural Science, 120(1), 88-94.

Whitaker, B. D. (2004). Oxidative stress and superficial scald of apple fruit. Hortscience, 39(5), 933-937.

Wiersma, P. A., Zhang, H. Y., Lu, C. W., Quail, A., \& Toivonen, P. M. A. (2007). Survey of the expression of genes for ethylene synthesis and perception during maturation and ripening of 'Sunrise' and 'Golden Delicious' apple fruit. Postharvest Biology and Technology, 44(3), 204-211. doi:10.1016/j.postharvbio.2006.12.016

Yang, S. F., \& Hoffman, N. E. (1984). Ethylene Biosynthesis and Its Regulation in HigherPlants. Annual Review of Plant Physiology and Plant Molecular Biology, 35, 155-189. doi:10.1146/annurev.pp.35.060184.001103

Yang, X., Song, J., Campbell-Palmer, L., Fillmore, S., \& Zhang, Z. (2013). Effect of ethylene and 1-MCP on expression of genes involved in ethylene biosynthesis and perception during ripening of apple fruit. Postharvest Biology and Technology, 78, 55-66. doi:10.1016/j.postharvbio.2012.11.012

Yuan, R., \& Carbaugh, D. H. (2007). Effects of NAA, AVG, and 1-MCP on ethylene biosynthesis, preharvest fruit drop, fruit maturity, and quality of 'Golden supreme' and 'Golden delicious' apples. Hortscience, 42(1), 101-105. 
Zeng, F., Luo, Z., Xie, J., \& Feng, S. (2015). Gamma radiation control quality and lignification of bamboo shoots (Phyllostachys praecox f. prevemalis.) stored at low temperature. Postharvest Biology and Technology, 102, 17-24. doi:10.1016/j.postharvbio.2015.02.004

Zhou, S., Cheng, Y., \& Guan, J. (2017). The molecular basis of superficial scald development related to ethylene perception and alpha-farnesene metabolism in 'Wujiuxiang' pear. Scientia Horticulturae, 216, 76-82. doi:10.1016/j.scienta.2016.12.025 